AperTO - Archivio Istituzionale Open Access dell'Università di Torino

\title{
Luminescent coordination polymers of 2,2'-bipyrimidine and mercury(II) salts: a structural and computational study
}

\section{This is the author's manuscript}

Original Citation:

Availability:

This version is available http://hdl.handle.net/2318/1551323

since 2016-01-28T20:55:27Z

Published version:

DOI:10.1016/j.poly.2015.10.059

Terms of use:

Open Access

Anyone can freely access the full text of works made available as "Open Access". Works made available under a Creative Commons license can be used according to the terms and conditions of said license. Use of all other works requires consent of the right holder (author or publisher) if not exempted from copyright protection by the applicable law. 
Questa è la copia dell'autore del lavoro pubblicato su POLYHEDRON, doi:10.1016/i.poly.2015.10.059

Volume 104, 28 January 2016, Pages 25-36 


\title{
Luminescent coordination polymers of 2,2'-bipyrimidine and mercury(II) salts: a structural and computational study
}

\author{
Emanuele Priola $^{\mathrm{a}, \mathrm{b}}$, Elisabetta Bonometti ${ }^{\mathrm{a}, \mathrm{b}}$, Valentina Brunella $^{\mathrm{a}}$, Lorenza Operti ${ }^{\mathrm{a}, \mathrm{b}}$, Eliano Diana ${ }^{\mathrm{a}, \mathrm{b} *}$ \\ ${ }^{a}$ Dipartimento di Chimica, Università di Torino-Via Pietro Giuria 7, Turin, Italy. \\ Tel: +39-0116707572 Fax: +39 0116707855 \\ e-mail: eliano.diana@unito.it. \\ ${ }^{\mathrm{b}}$ CrisDi-Interdepartmental Center for Crystallography, University of Torino, Turin, Italy
}

\begin{abstract}
We report the synthesis and structural, thermal and vibrational characterization of five complexes of the 2,2'bipyrimidine (bipym) with $\mathrm{HgX}_{2}, \mathrm{X}=\mathrm{Cl}, \mathrm{Br}, \mathrm{I}, \mathrm{CN}, \mathrm{SCN}$, with the aim to investigate the factors that could influence the supramolecular chemistry of mercury(II). The combination of the 2,2'-bipym ligand, a bidentate molecule, and bridging anions together with a $\mathrm{d}^{10}$ metal like mercury(II) has given different polymeric structures with $1 \mathrm{D}$ and $3 \mathrm{D}$ dimensionality. A computational modelling, compared to statistical analysis of reported structures, has allowed to rationalize the differing contribution of bipym and halide and pseudohalide ligands to supramolecular architecture. Solid state photoluminescent properties have been investigated and an interpretation based on computational models has been proposed.
\end{abstract}

\section{KEYWORDS}

Photoluminescence, supramolecular chemistry, coordination polymers, 2,2'-bipyrimidine, Mercury halogenides.

\section{Introduction}

Self-assembly of small building blocks to give supramolecular architectures is a vibrant area of research [1]. An interesting method of constructing complex molecules employs a "dynamic" coordination chemistry, with labile metal centers and bridging ligands used to form the primary structure, and weak, non-covalent interactions like hydrogen bonding, $\pi-\pi$ stacking, metallophilic interactions (especially for $\mathrm{d}^{10}$ metal compounds) [2] or secondary interactions in the metal sphere exploited to organize these primary structure into supramolecular materials [3]. The supramolecular chemistry of $\mathrm{Hg}$ (II) cation is a perfect candidate in this dynamical crystal engineering approach; the peculiar behavior of this heavy d $\mathrm{d}^{10}$ metal center is that its closed shell electronic configuration cannot be stabilized by crystal fields effects to a specific geometry and this allows strong distortions in the platonic polyhedron typical of transition metals and the presence of further weaker interactions into the coordination environment. These distortions are affected by the packing forces and by the donor strength of the coordinated ligands. Furthermore, the strong relativistic behavior of this metal allows a stable linear coordination, strong covalent bonds with many anionic or neutral ligands and the appearance of metallophilic interactions. The patterns obtained in the supramolecular structures of $\mathrm{Hg}$ (II) therefore are the result of a subtle balance of weak forces, and their control is quite difficult without a selective choice of the different building blocks [4]. These effects have been investigated in a series of complexes prepared by addition of an ancillary ligand to an inorganic cation-anion framework. We have studied the coordination of the 2,2'-bipyrimidine (bipym) to some $\mathrm{HgX}$ salts, with $\mathrm{X}_{2} \mathrm{Cl}^{-}, \mathrm{Br}^{-}, \mathrm{I}^{-} \mathrm{CN}^{-}$and $\mathrm{SCN}^{-}$. Some of these complexes have already been reported, but not fully characterized [5].These anions usually can bridge metal centers, but their arrangements is strongly influenced by the other constituents because of the peculiarities of $\mathrm{Hg}$ (II) above cited, and the bridging bonds are weaker than typical coordination polymer's interactions [6]. We have analyzed these effects through a structural, vibrational, thermal and computational study. Furthermore, this aromatic ligand was studied deeply for its interesting photochemical and photophysical properties: the presence of three low-energy $\pi^{*}$ antibonding levels, make this molecule a good $\pi$ acceptor [7] able to give high-intensities room temperature luminescence emissions. However, few studies have been reported about the luminescence of $\mathrm{d}^{10}$ metal complexes of bipym, and all focused on $\mathrm{Zn}(\mathrm{II})$ and $\mathrm{Cu}(\mathrm{I})$. In the zinc complexes, metal-ligand interactions are interpreted not unambiguously: their effect seems to have a modest effect on the electronic transitions of the ligand itself [8], or a MLCT is invoked[9]. For Cu(I) complexes of POP (bis $\{2$-(diphenylphosphanyl) phenyl $\}$ ether) and phosphine a huge increase of the intensity of the luminescence and the apparition of new MLCT bands are reported [10]. However, all the studies mainly focused on molecular complexes and to our knowledge no detailed investigation have been reported on the luminescence of coordination polymers of bipym with $\mathrm{d}^{10}$ metals. Within this background we measured and analysed the luminescence of the title compounds. 


\section{Experimental}

\section{Chemicals and Reagents}

All chemicals were used as purchased without further purification: $\mathrm{HgCl}_{2}\left(99.9 \%\right.$, Schiapparelli), $\mathrm{HgI}_{2}(99.0 \%$, SigmaAldrich), $\mathrm{HgBr}_{2}\left(99.0 \%\right.$, Sigma-Aldrich), $\mathrm{Hg}(\mathrm{CN})_{2}$ (99.0\%,Aldrich), $\mathrm{Hg}(\mathrm{SCN})_{2}$ (99.0\%, Fluka), 2,2'-bipyrimidine (bipym) (99.0\%,Sigma-Aldrich).

\section{Synthesis of $\left[\mathrm{HG}_{2}(\mathrm{BIPYM}) \mathrm{X}_{4}\right] \mathrm{X}(\mathrm{X}=\mathrm{CL}(1), \mathrm{BR}(2), \mathrm{I}(3), \mathrm{CN}(4), \operatorname{SCN}(5))$}

Lanza (for the chloride binuclear complex) [5a] and Jarabat (for the halides binuclear complexes) [5b] proposed a synthetic procedure consisting in the mixing of solutions of the inorganic salt and the organic ligand in water, ethanol or acetone (depending on the solubility of the salt) and obtained powder pure compounds. We decided to modify this methodology in order to obtain crystalline samples: a) A solution of bipym (50 mg, $0.32 \mathrm{mmol})$ in $2 \mathrm{ml}$ of acetonitrile and a solution of $\mathrm{HgX}_{2}(\mathrm{X}=\mathrm{Cl}, \mathrm{Br}, \mathrm{I}, \mathrm{CN}, \mathrm{SCN})(0.64 \mathrm{mmol})$ in $20 \mathrm{ml}$ of acetonitrile were mixed, with immediate formation of a precipitate (not relevant for cyanide and chloride salts), and the yellow mixture obtained was refluxed for 2 days, until the solution became orange and transparent. The solution has been concentrated at $25^{\circ} \mathrm{C}$ and orange prismatic crystals were obtained and separated, suitable for X-ray analysis. For better crystals of $\mathbf{5}$, the initial small acicular crystalline product has been redissolved in acetone at room temperature; after a week, prismatic orange crystals have been obtained. b) We also performed the synthesis of the various complexes in solvothermal conditions, with the previous quantity of reagents mixed in $100 \mathrm{ml}$ of acetonitrile. The reaction was performed at $150^{\circ} \mathrm{C}$ for $12 \mathrm{~h}$, and after cooling gave the same crystalline phases obtained with the first procedure. All the products have been analysed with powder X-ray diffraction and Raman spectroscopy to check the purity, and there are no relevant peaks of other phases or impurity.

\section{X-Ray crystallography}

Data of single crystals of compound 1, 2, 3, 4 and 5 have been collected on a Gemini R Ultra diffractometer [11]. All data were collected using graphite-monochromated Mo K $\alpha$ radiation $(\lambda=0.71073)$ with the $\omega$-scan method. Cell parameters were retrieved using CrysAlisPro[12] software, and the same program have been used for performing data reduction, with correction for Lorenz and polarizing effects. Scaling and absorption correction were applied by CrysAlisPro[12] multi-scan technique. All structures were solved by direct methods using SHELXS-97[13] and refined with full-matrix least-squares on $\mathrm{F}^{2}$ using the SHELXL-97[13]. All non-hydrogen atoms have been anisotropically refined. Hydrogen atoms have been located in the final Fourier-difference maps and refined with coordinates and $U_{\text {iso }}$ free (compound 1, 4 and 5 ) or calculated and riding on the corresponding $\mathrm{C}$ atom (compound $\mathbf{2}$ and 3). Structural illustrations have been drawn with CrystalMaker ${ }^{\circledR}$ : a crystal and molecular structures program for Mac and Windows[14]. The powder diffraction measurements have been recorded with the same instrument, using $\mathrm{Cu}(\mathrm{K} \alpha)$ radiation on the milled samples. Crystal data and refinement results could be found in Table 1. Main distances and angle are reported in Table 2. As expected, the highest peaks and deepest holes for these mercury complexes are slightly high, but the residual densities are close to heavy mercury atoms. Crystallographic data of compound 1, 3, $\mathbf{4}$ and $\mathbf{5}$ have been deposited to ICSD with CSD number 1028414-1028417; compound 2 with CCDC 1412102. 


\begin{tabular}{|c|c|c|c|}
\hline & Crystal 1 & Crystal 2 & Crystal 3 \\
\hline Empirical formula & $\mathrm{C}_{4} \mathrm{H}_{3} \mathrm{Cl}_{2} \mathrm{Hg} \mathrm{N} \mathrm{N}_{2}$ & $\mathrm{C}_{4} \mathrm{H}_{3} \mathrm{Br}_{2} \mathrm{Hg} \mathrm{N} \mathrm{N}_{2}$ & $\mathrm{C}_{4} \mathrm{H}_{3} \mathrm{Hg} \mathrm{I}_{2} \mathrm{~N}_{2}$ \\
\hline Formula weight & 350.57 & 251.14 & 533.47 \\
\hline Temperature & $293(2) \mathrm{K}$ & $273(2) \mathrm{K}$ & $293(2) \mathrm{K}$ \\
\hline Wavelenght & 0.71073 & 0.71073 & 0.71073 \\
\hline Crystal system, spacegroup & Monoclinic, $\mathrm{P} 2{ }_{1} / \mathrm{n}$ & Monoclinic, $\mathrm{P} 2{ }_{1} / \mathrm{n}$ & Orthorombic, Pnma \\
\hline Unit cell dimensions & $\begin{array}{c}\mathrm{a}=3.9406(2) \AA \\
\mathrm{b}=18.935(1) \AA \\
\mathrm{c}=9.5633(6) \AA \\
\boldsymbol{\beta}=\mathbf{1 0 1 . 8 9 ( 1 )}\end{array}$ & $\begin{array}{l}a=4.1032(3) \\
b=19.427(2) \\
c=9.7526(6) \\
\beta=\mathbf{1 0 2 . 0 6 9 ( 7 )}\end{array}$ & $\begin{array}{c}\mathrm{a}=7.014(1) \AA \\
\mathrm{b}=19.269(4) \AA \\
\mathrm{c}=12.399(3) \AA\end{array}$ \\
\hline Volume & $698.27(7) \AA^{3}$ & $760.23(10) \AA^{3}$ & $1675.8(6) \AA^{3}$ \\
\hline Z, calculated density & $4,3.335 \mathrm{~g} / \mathrm{cm}^{3}$ & $7,3.840 \mathrm{~g} / \mathrm{cm}^{3}$ & $8,4.229 \mathrm{~g} / \mathrm{cm}^{3}$ \\
\hline Abs.coeff. $\mu$ & $22.709 \mathrm{~mm}^{-1}$ & $30.668 \mathrm{~mm}^{-1}$ & $25.657 \mathrm{~mm}^{-1}$ \\
\hline $\mathrm{F}(000)$ & 620 & 764 & 1816 \\
\hline Crystal size & $0.113 \times 0.128 \times 0.295 \mathrm{~mm}$ & $0.05 \times 0.2 \times 0.4 \mathrm{~mm}$ & $0.093 \times 0.134 \times 0.332 \mathrm{~mm}$ \\
\hline$\theta$ range for data collec. & $3.89-32.27 \mathrm{deg}$ & $3.7956-29.2834 \mathrm{deg}$ & $3.29-29.25 \mathrm{deg}$ \\
\hline Limiting indices & $\begin{array}{c}-5<=\mathrm{h}<=5 \\
-27<=\mathrm{k}<=28 \\
-13<=1<=14\end{array}$ & $\begin{array}{c}-4<=\mathrm{h}<=5 \\
-24<=\mathrm{k}<=24 \\
-13<=1<=11\end{array}$ & $\begin{array}{c}-9<=\mathrm{h}<=9 \\
-25<=\mathrm{k}<=26 \\
-16<=1<=16\end{array}$ \\
\hline Refl. collected/unique & $14437 / 2332[\mathrm{R}($ int $)=0.0777]$ & $5529 / 1810[\mathrm{R}(\mathrm{int})=0.0438]$ & $26105 / 2258[\mathrm{R}($ int $)=0.0566]$ \\
\hline Compl.ness to theta & $94.1 \%$ & $86.6 \%$ & $96.3 \%$ \\
\hline Refinement method & Full matrix least square on $\mathrm{F}^{2}$ & Full matrix least square on $\mathrm{F}^{2}$ & Full matrix least square on $\mathrm{F}^{2}$ \\
\hline Data/restrains/parameters & $2332 / 54 / 83$ & $1810 / 0 / 82$ & $2258 / 0 / 92$ \\
\hline Goodness-of-fit on $\mathrm{F}^{2}$ & 0.951 & 1.069 & 1.077 \\
\hline Final $\mathrm{R}$ indices[I>2 $\sigma(\mathrm{I})]$ & $\mathrm{R} 1=0.0356, \mathrm{wR} 2=0.0712$ & $\mathrm{R} 1=0.04380, \mathrm{wR} 2=0.0854$ & $\mathrm{R} 1=0.0391, \mathrm{wR} 2=0.1066$ \\
\hline $\mathrm{R}$ indices (all data) & $\mathrm{R} 1=0.0534, \mathrm{wR} 2=0.0791$ & $\mathrm{R} 1=0.0603, \mathrm{wR} 2=0.0929$ & $\mathrm{R} 1=0.0525, \mathrm{wR} 2=0.1158$ \\
\hline \multicolumn{4}{|l|}{ Exctintion coefficient } \\
\hline Largest diff. peaks and hole & 1.821 and $-2.507 \mathrm{e}^{-3}$ & 1.625 and $-1.237 \mathrm{eA}^{-3}$ & 2.204 and $-2.235 \mathrm{eA}^{-3}$ \\
\hline
\end{tabular}

\begin{tabular}{|c|c|c|}
\hline & Crystal 4 & Crystal 5 \\
\hline Empirical formula & $\mathrm{C}_{6} \mathrm{H}_{4} \mathrm{HgN}_{4} \mathrm{O}_{0.5}$ & $\mathrm{C}_{12} \mathrm{H}_{6} \mathrm{Hg}_{2} \mathrm{~N}_{8} \mathrm{~S}_{4}$ \\
\hline Formula weight & 340.72 & 791.67 \\
\hline Temperature & $293(2) \mathrm{K}$ & $293(2) \mathrm{K}$ \\
\hline Wavelenght & 0.71073 & 0.71073 \\
\hline Crystal system, spacegroup & Monoclinic , C2/c & Monoclinic, $\mathrm{P} 2{ }_{1} / \mathrm{c}$ \\
\hline Unit cell dimensions & $\begin{array}{c}\mathrm{a}=12.07064(4) \AA \\
\mathrm{b}=7.1711(2) \AA \\
\mathrm{c}=17.7626(5) \AA \\
\beta=91.915(3)\end{array}$ & $\begin{array}{c}\mathrm{a}=10.5327(4) \AA \\
\mathrm{b}=11.7056(4) \AA \\
\mathrm{c}=16.0828(6) \AA \\
\boldsymbol{\beta}=\mathbf{1 0 4 . 2 6 2}(\mathbf{4})\end{array}$ \\
\hline Volume & $1614.73(8) \AA^{3}$ & $1921.76(12) \AA^{3}$ \\
\hline $\mathrm{Z}$, calculated density & $8,2.803 \mathrm{~g} / \mathrm{cm}^{3}$ & $4,2.736 \mathrm{~g} / \mathrm{cm}^{3}$ \\
\hline Abs.coeff. $\mu$ & $19.008 \mathrm{~mm}^{-1}$ & $38.324 \mathrm{~mm}^{-1}$ \\
\hline $\mathrm{F}(000)$ & 1216 & 1432 \\
\hline Crystal size & $0.060 \times 0.065 \times 0.160 \mathrm{~mm}$ & $0.044 \times 0.116 \times 0.496 \mathrm{~mm}$ \\
\hline$\theta$ range for data collec. & $3.42-29.21 \mathrm{deg}$ & $3.36-29.25 \mathrm{deg}$ \\
\hline Limiting indices & $\begin{array}{c}-17<=\mathrm{h}<=17 \\
-9<=\mathrm{k}<=9 \\
-24<=\mathrm{l}<=24\end{array}$ & $\begin{array}{c}-14<=\mathrm{h}<=10 \\
-15<=\mathrm{k}<=13 \\
-15<=\mathrm{l}<=22\end{array}$ \\
\hline Refl. collected/unique & $12544 / 2045[\mathrm{R}(\mathrm{int})=0.058]$ & $8929 / 4333$ [R(int $)=0.0267]$ \\
\hline Compl.ness to theta & $93.8 \%$ & $82.7 \%$ \\
\hline Refinement method & Full matrix least square on $\mathrm{F}^{2}$ & Full matrix least square on $\mathrm{F}^{2}$ \\
\hline Data/restrains/parameters & $2045 / 87 / 110$ & $4333 / 198 / 235$ \\
\hline Goodness-of-fit on $\mathrm{F}^{2}$ & 1.037 & 1.021 \\
\hline Final $\mathrm{R}$ indices $[\mathrm{I}>2 \sigma(\mathrm{I})]$ & $\mathrm{R} 1=0.0232, \mathrm{wR} 2=0.0452$ & $\mathrm{R} 1=0.0282, \mathrm{wR} 2=0.0490$ \\
\hline $\mathrm{R}$ indices (all data) & $\mathrm{R} 1=0.0361, w \mathrm{w} 2=0.0503$ & $\mathrm{R} 1=0.0435, \mathrm{wR} 2=0.0536$ \\
\hline Exctintion coefficient & $0.00123(6)$ & \\
\hline Largest diff. peaks and hole & 1.013 and $-0.929 \mathrm{eA}^{-3}$ & 0.922 and $-0.714 \mathrm{e}^{-3}$ \\
\hline
\end{tabular}

Table 1. Summary of crystallographic data for all complexes 


\begin{tabular}{|c|c|c|c|c|c|}
\hline $\begin{array}{c}\text { Complex } 1 \\
\mathrm{X}=\mathrm{Cl}\end{array}$ & $\begin{array}{c}\text { Complex } 2 \\
\mathrm{X}=\mathrm{Br}\end{array}$ & $\begin{array}{c}\text { Complex } 3 \\
\text { X=I }\end{array}$ & $\begin{array}{c}\text { Complex } 4 \\
\mathrm{x}=\mathrm{CN}\end{array}$ & $\begin{array}{c}\text { Complex } 5 \\
\text { (molec. 1) } \\
\text { X=SCN }\end{array}$ & $\begin{array}{c}\text { Complex } 5 \\
\text { (molec. 2) } \\
\text { X=SCN }\end{array}$ \\
\hline $\begin{array}{c}\mathrm{Hg}(1)-\mathrm{Cl}(2) \\
2.3483(14)\end{array}$ & $\begin{array}{c}\mathrm{Hg}(1)-\mathrm{Br}(2) \\
2.4619(12)\end{array}$ & $\begin{array}{c}\mathrm{Hg}(1)-\mathrm{I}(1) \\
2.6064(8)\end{array}$ & $\begin{array}{c}\mathrm{Hg}(1)-\mathrm{C}(6) \\
2.048(5)\end{array}$ & $\begin{array}{l}\mathrm{Hg}(1)-\mathrm{S}(1) \\
2.4153(13)\end{array}$ & $\begin{array}{l}\mathrm{Hg}(2)-\mathrm{S}(4) \\
2.3856(17)\end{array}$ \\
\hline $\begin{array}{c}\mathrm{Hg}(1)-\mathrm{Cl}(1) \\
2.3600(15)\end{array}$ & $\begin{array}{c}\mathrm{Hg}(1)-\mathrm{Br}(1) \\
2.4831(11)\end{array}$ & $\begin{array}{l}\mathrm{Hg}(1)-\mathrm{I}(2) \\
2.6077(9)\end{array}$ & $\begin{array}{c}\mathrm{Hg}(1)-\mathrm{C}(5) \\
2.068(5)\end{array}$ & $\begin{array}{l}\mathrm{Hg}(1)-\mathrm{S}(2) \\
2.4441(13)\end{array}$ & $\begin{array}{l}\mathrm{Hg}(2)-\mathrm{S}(3) \\
2.4169(14)\end{array}$ \\
\hline $\begin{array}{c}\mathrm{Hg}(1)-\mathrm{N}\left(2^{\mathrm{i}}\right) \\
2.575(5)\end{array}$ & $\begin{array}{c}\mathrm{Hg}(1)-\mathrm{N}\left(2^{\mathrm{i}}\right) \\
2.593(8)\end{array}$ & $\begin{array}{c}\mathrm{Hg}(1)-\mathrm{N}(2) \\
2.681(7)\end{array}$ & $\begin{array}{c}\mathrm{Hg}(1)-\mathrm{N}\left(2^{\mathrm{i}}\right) \\
2.641(3)\end{array}$ & $\begin{array}{c}\mathrm{Hg}(1)-\mathrm{N}\left(1^{\mathrm{i}}\right) \\
2.469(4)\end{array}$ & $\begin{array}{c}\mathrm{Hg}(2)-\mathrm{N}\left(4^{\mathrm{ii}}\right) \\
2.523(4)\end{array}$ \\
\hline \multirow[t]{2}{*}{$\begin{array}{c}\mathrm{Hg}(1)-\mathrm{N}(1) \\
2.617(4) \\
\end{array}$} & $\begin{array}{c}\mathrm{Hg}(1)-\mathrm{N}(1) \\
2.640(9) \\
\end{array}$ & $\begin{array}{c}\mathrm{Hg}(1)-\mathrm{I}\left(1^{\mathrm{i}}\right) \\
3.3299(9) \\
\end{array}$ & $\begin{array}{c}\mathrm{Hg}(1)-\mathrm{N}(1) \\
2.650(3) \\
\end{array}$ & $\begin{array}{c}\mathrm{Hg}(1)-\mathrm{N}(2) \\
2.513(4) \\
\end{array}$ & $\begin{array}{c}\mathrm{Hg}(2)-\mathrm{N}(3) \\
2.535(4) \\
\end{array}$ \\
\hline & & & & $\begin{array}{c}\mathrm{Hg}(1)-\mathrm{N}(31) \\
2.661(5) \\
\end{array}$ & \\
\hline $\begin{array}{c}\mathrm{Cl}(2)-\mathrm{Hg}(1)-\mathrm{Cl}(1) \\
147.53(6)\end{array}$ & $\begin{array}{c}\mathrm{Br}(2)-\mathrm{Hg}(1)-\mathrm{Br}(1) \\
146.34(4)\end{array}$ & $\begin{array}{c}\mathrm{I}(1)-\mathrm{Hg}(1)-\mathrm{I}(2) \\
160.23(3)\end{array}$ & $\begin{array}{c}\mathrm{C}(6)-\mathrm{Hg}(1)-\mathrm{C}(5) \\
164.86(18)\end{array}$ & $\begin{array}{c}\mathrm{S}(1)-\mathrm{Hg}(1)-\mathrm{S}(2) \\
138.84(5)\end{array}$ & $\begin{array}{c}\mathrm{S}(4)-\mathrm{Hg}(2)-\mathrm{S}(3) \\
153.18(5)\end{array}$ \\
\hline $\begin{array}{c}\mathrm{N}\left(2^{\mathrm{i}}\right)-\mathrm{Hg}(1)-\mathrm{N}(1) \\
63.09(14)\end{array}$ & $\begin{array}{c}\mathrm{N}\left(2^{\mathrm{i}}\right)-\mathrm{Hg}(1)-\mathrm{N}(1) \\
62.3(2)\end{array}$ & $\begin{array}{c}\mathrm{Hg}(1)-\mathrm{I}(1)-\mathrm{Hg}\left(1^{\mathrm{i}}\right) \\
91.01(3)\end{array}$ & $\begin{array}{c}\mathrm{N}\left(2^{\mathrm{i}}\right)-\mathrm{Hg}(1)-\mathrm{N}(1) \\
61.90(11)\end{array}$ & $\begin{array}{c}\mathrm{N}\left(1^{\mathrm{i}}\right)-\mathrm{Hg}(1)-\mathrm{N}(2) \\
66.16(14)\end{array}$ & $\begin{array}{c}\mathrm{N}\left(4^{\mathrm{ii}}\right)-\mathrm{Hg}(2)-\mathrm{N}(3) \\
64.85(13)\end{array}$ \\
\hline
\end{tabular}

Table 2. Bond lengths $[\AA]$ and angles $[\mathrm{deg}]$ of complexes (symmetry codes for the structures: Complex $1(\mathrm{i})=-\mathrm{x}+2,-\mathrm{y},-\mathrm{z}+1, \mathrm{Complex} 2(\mathrm{i})=-\mathrm{x}+1,-\mathrm{y},-$ $\mathrm{z}+1$, Complex 3 (i) =-x,-y+1,-z ,Complex $4(\mathrm{i})=-\mathrm{x}+1 / 2,-\mathrm{y}+1 / 2,-\mathrm{z}+1$, Complex $5(\mathrm{i})=-\mathrm{x}+1,-\mathrm{y}+1,-\mathrm{z},(\mathrm{ii})=-\mathrm{x},-\mathrm{y},-\mathrm{z}$,

\section{Spectral analysis}

FTIR and FT-Raman spectra were obtained with a Bruker Vertex 70 spectrophotometer, equipped with the RAMII accessory. We recorded spectra with a resolution of $2 \mathrm{~cm}^{-1}$. Infrared spectra were obtained from $\mathrm{KBr}$ pellets. Raman spectra were obtained from crystalline sample, by exciting with a $1064 \mathrm{~nm}$ radiation.

The UV-VIS spectra were recorded on crystalline sample by employing a Perkin Elmer Lambda 900 spectrophotometer in reflectance mode. The photoluminescence measurements were recorded using a Fluorolog F2 Horiba/Jobin-Yvon spectrofluorometer.

\section{Thermal analysis}

A differential scanning calorimeter (DSC Q200, TA Inc.), provided with a cooling system RCS90, was used to collect DSC thermograms. The DSC measurements were performed with closed aluminum pan under nitrogen atmosphere $(50 \mathrm{~cm} / \mathrm{min})$ and with a $10^{\circ} \mathrm{C} / \mathrm{min}$ heating rate, from $20^{\circ} \mathrm{C}$ up to $180^{\circ} \mathrm{C}$.

Thermal stability was evaluated with a Hi-Res thermo gravimetric analyzer (TGA Q500 balance, TA Inc.) on 10-15 mg sample contained in alumina pans, with a $10^{\circ} \mathrm{C} / \mathrm{min}$ heating ramp from $50^{\circ} \mathrm{C}$ up to $700^{\circ} \mathrm{C}$ under a $100 \mathrm{~cm}^{3} / \mathrm{min}_{\text {nitrogen }}$ flow.

\section{Computational analysis}

DFT calculation of molecular models were carried out with Gaussian09 package [15] by employing the B3PW91 hybrid functional. We used the 6-31++g(2d,2p) for $\mathrm{H}, \mathrm{C}, \mathrm{N}, \mathrm{O}, \mathrm{S}$ and $\mathrm{Cl}$ atoms, and the ECP60MWB quasi-relativistic pseudopotential and a $(8 \mathrm{~s} 7 \mathrm{p} 6 \mathrm{~d} 2 \mathrm{f} 1 \mathrm{~g}) /[6 \mathrm{~s} 5 \mathrm{p} 3 \mathrm{~d} 2 \mathrm{f} 1 \mathrm{~g}]$ basis set for $\mathrm{Hg}$ [16] and the ECP46MWB pseudopotential[17] and $(14 \mathrm{~s} 10 \mathrm{p} 3 \mathrm{~d} 1 \mathrm{f}) /[3 \mathrm{~s} 3 \mathrm{p} 2 \mathrm{~d} 1 \mathrm{f}]$ basis set for iodine [18]. All structure were optimized to an energy minimum and harmonic vibrational frequencies computed. Electronic spectra have been computed by means of Hartree-Fock configuration 
interaction method with single and double excitations, on optimized geometry obtained with a 6-31g(d) basis set for $\mathrm{H}, \mathrm{C}, \mathrm{N}, \mathrm{O}, \mathrm{S} \mathrm{Cl}$ and $\mathrm{Br}$ atoms and the LANL2DZ basis set and pseudopotential for $\mathrm{Hg}$ and I atoms.

The band structure of crystalline solids has been computed with Crystal09[19] package, at Hartree-Fock level, with a 6$31 \mathrm{~g}(\mathrm{~d})$ basis set for light elements and the previously cited ECP pseudopotential and basis set for $\mathrm{Hg}$ and I.

\section{Results}

\section{X-ray structures}

2,2'-bipyrimidine has four nitrogen atoms that act as basis towards the $\mathrm{Hg}$ (II) ions, giving rise to structures containing two $\mathrm{HgX}_{2}\left(\mathrm{X}=\mathrm{Cl}^{-}, \mathrm{CN}^{-}, \mathrm{I}^{-}, \mathrm{SCN}^{-}, \mathrm{Br}^{-}\right)$moieties for ligand (figure 1). The complexes $\mathbf{1}, \mathbf{2}, \mathbf{3}$ and 5 lay on a crystallographic inversion center, while complex 4 lays on a crystallographic mirror plane. In all complexes $\mathrm{Hg}$ (II) has a distorted tetrahedral coordination.

\section{Crystal packing}

Complex 1




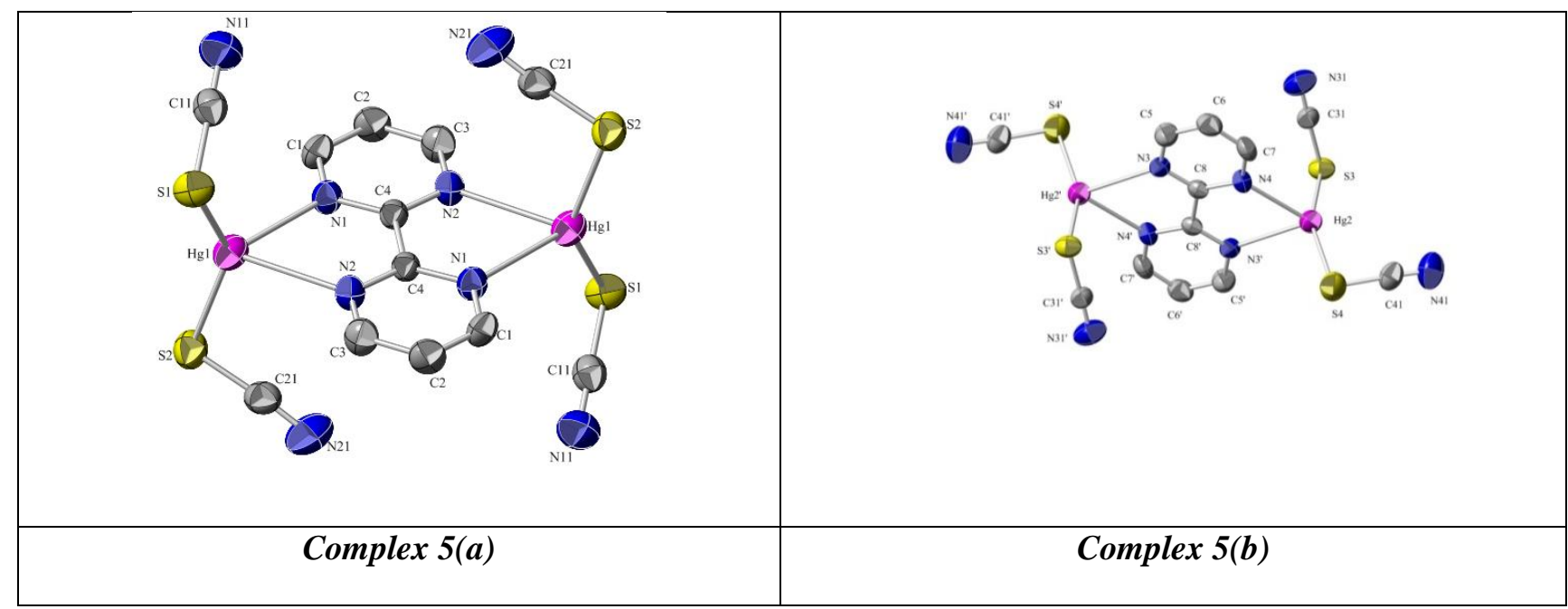

Figure 1. Molecular structure of complexes 1-5. Hydrogen atoms are omitted for clarity (ORTEP plot 50\%)

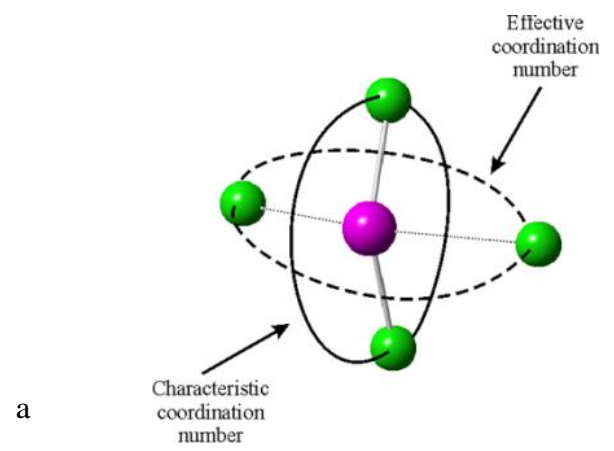

\begin{tabular}{|c|c|c|}
\hline & $\begin{array}{c}\text { Characteristic } \\
\text { Coordination number }\end{array}$ & $\begin{array}{c}\text { Effective Coordination } \\
\text { number }\end{array}$ \\
\hline Complex 1 & 4 & 6 \\
\hline Complex 2 & 4 & 6 \\
\hline Complex 3 & 4 & 5 \\
\hline Complex 4 & 4 & 5 \\
\hline Complex 5(a) & 4 & 5 \\
\hline Complex 5(b) & 4 & 6 \\
\hline
\end{tabular}

b

Figure 2: Graphical representation of characteristic coordination number and effective coordination number (a) and data for our compounds

\section{Complex 1 and 2}

The coordination sphere of $\mathrm{Hg}$ (II) could be analyzed by means of two coordination numbers: characteristic coordination number defined by nearest neighbors atoms, and effective coordination number that is obtained by including all ligands within the Van Der Waals radii sum (figure 2) [20]. This distinction is due to the strong tendency of $\mathrm{Hg}$ to have linear or low coordination number [21]. In 1 and 2 the mercury has a characteristic coordination number of four defined by the $\mathrm{N}-\mathrm{Hg}$ bonds and the strong $\mathrm{Hg}-\mathrm{Cl}(1)$ and $\mathrm{Hg}$ $\mathrm{Cl}(2)$ interactions $(\mathrm{Hg}-\mathrm{Br}(1)$ and $\mathrm{Hg}-\mathrm{Br}(2))$, as highlighted by the $\mathrm{Hg}-\mathrm{Cl}$ distances $(\mathrm{Hg}-\mathrm{Br}$ in 2) (see Table 2). Effective coordination number is obtained by adding two weaker additional interactions between $\mathrm{Hg}(\mathrm{II})$ and the atoms $\mathrm{Cl}\left(1^{\mathrm{ii}}\right)$ and $\mathrm{Cl}\left(2^{\mathrm{iii}}\right)(3.096(2) \AA$ and $3.219(2) \AA)\left(\operatorname{Br}\left(1^{\mathrm{ii}}\right)\right.$ and $\operatorname{Br}\left(2^{\mathrm{iii}}\right)(3.228(1) \AA$ and $3.445(1) \AA)$ in 2$)($ symmetry codes: (ii) $=\mathrm{x}-1, \mathrm{y} \mathrm{z},(\mathrm{iii})=\mathrm{x}+2, \mathrm{y}, \mathrm{z})$. The octahedron generated by effective coordination number is highly distorted, and this is typical of the chemistry of $\mathrm{d}^{10}$ metals because the absence of effects that stabilize platonic polyhedra. The two aromatic rings of the 2,2'-bipyrimidine are coplanar and not distorted by the complexation and form a 1D ladder-type coordination polymer based on the weaker inter-unit $\mathrm{Hg}(\mathrm{II}) \cdots \mathrm{Cl}(\mathrm{Br})$ interactions that grows along the a-axis (figure 3). The structure of 1 and 2 are isomorphous, with slight distortion for the greater dimensions of the bromine in respect of chlorine. The metal centers are connected through two bridging chlorides that form $\mathrm{Hg}_{2} \mathrm{Cl}_{2}$ asymmetric lozenge rings with angles of $84.75(7)^{\circ}$ and $91.48(7)^{\circ}$ centered at the $\mathrm{Hg}(1)$ atom and at $\mathrm{Cl}(1)$ atom and similar for bromine. The distances between metal centers (3.941(1) $\AA$ in 1 and 4.103(1) $\AA$ in 2) are not indicative of strong metallophilic interactions [22] The ladder disposition of inorganic chains is not so common in the chemistry of bipym, and only three examples are reported in the literature [23]. However, in mercury complexes lozenge disposition of bridging chloride is quite common, and some 1D polymers with this ladder chain are reported, especially with pyrazine and its derivatives [24], while is less common for bromine compounds. 


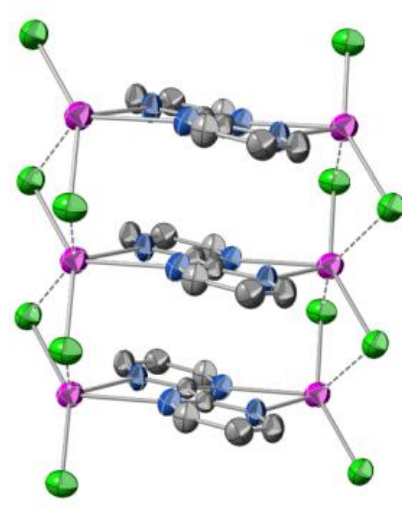

Figure 3. Crystal packing of 1 along a direction. Hydrogen atoms are omitted for clarity (ORTEP plot 50\%)

\section{Complex 3}

In complex $3 \mathrm{Hg}(1)$ atom maintains a characteristic coordination number of four, with $\mathrm{Hg}-\mathrm{I}$ and $\mathrm{Hg}-\mathrm{N}$ bonds very similar (table 2). Unlike $\mathbf{1}$ and $\mathbf{2}$, the effective coordination number is five, and the additional weaker bond is with the iodide of the nearest binuclear complex $\left(\mathrm{d}\left(\mathrm{Hg}(1)-\mathrm{I}\left(1^{\mathrm{i}}\right)\right)=3.3299(9) \AA\right)$. The coordination geometry is a trigonal bipyramid lightly distorted in the central plane: the $\tau$-deformation parameter for trigonality [25] is 0.99 ( 1 in a perfect trigonal bipyramid). The $\mathrm{Hg} \cdots \mathrm{I}$ interactions form the dimeric fragment $\mathrm{Hg}_{2} \mathrm{I}_{4}$, that is quite common in the chemistry of the iodomercurates [26,27]: in our complex, the rhomboidal planar lozenge $\mathrm{Hg}_{2} \mathrm{I}_{2}$ has non-symmetric bridging anions with angles of $91.01(3)^{\circ}$ at the iodides and $89.93(3)^{\circ}$ at the mercury atoms. The distance between metal centres is $4,265(1) \AA$, indicating the lack of mercurophilic interactions. By respect complexes 1 and 2, the five atoms $\mathrm{Hg}-\mathrm{N}(1)-\mathrm{C}(1)-\mathrm{C}(2)-\mathrm{N}(2)$ ring are not planar because the half-chair conformation due to $\mathrm{Hg}$ (II) position. This distortion reflects on the organic ligand, that is bent along the C1-C2 inter-ring bond with a torsion of the rings of $2.79(6)^{\circ}$. The association of the bridging bipym with iodide originates a 1D ribbon-like coordination polymer that runs through the weak interactions along the c-axis (figure 4). This is a typical structural pattern of the bipym ligand, that can form ribbon with or without the help of other anionic bridges [27].

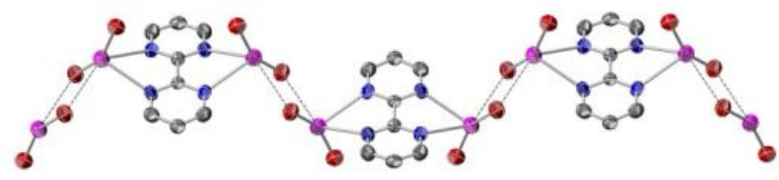

Figure 4. Polymer expansion along c-axis in 3. Hydrogen atoms are omitted for clarity (ORTEP plot 50\%)

\section{Complex 4}

$\mathrm{Hg}(1)$ has four short interactions with the two cyanide and with the $\mathrm{N}$ atoms of bipym (table 2). The effective coordination number is five because the interaction with the cyanide nitrogen of an adjacent molecule $\left(\mathrm{d}\left(\mathrm{Hg}(1)-\mathrm{N}\left(6^{\mathrm{ii}}\right)\right)=2,991(5) \AA\right)($ symmetry code: $(\mathrm{ii})=-\mathrm{x}+1 / 2, \mathrm{y}-1 / 2,-\mathrm{z}+5 / 2)$. The polyhedron is highly distorted, but the analysis of the $\tau$ parameter with a value of 0.89 suggest a coordination geometry more similar to a triangular bypiramid. The aromatic rings of the 2,2 ' bipirymidine are coplanar and undistorted by the complexation. The water molecule is situated in the spaces between the bimetallic units of the structure, and bridges the $\left[\mathrm{Hg}_{2}(\right.$ bipym $\left.)(\mathrm{CN})_{4}\right]$ units along the a-axis through strong hydrogen bonds with cyanide ligands $(\mathrm{d}(\mathrm{O}(1)-\mathrm{N}(6))=3.116(5) \AA$, $\operatorname{ang}(\mathrm{O}(1)-\mathrm{H}(1) \ldots \mathrm{N}(6))=154.44(10)$ (figure 5). The importance of hydrogen bond in the crystallochemistry of $\mathrm{Hg}(\mathrm{CN})_{2}$ derivatives is well established and it could be one of the main driving force of the structure packing [28]. On the other hand, cyanides bridging mercury atoms are very rare: in 4 the N(6) atom has a weak interaction with $\mathrm{Hg}(1)(\mathrm{d}(\mathrm{N}(6)-\mathrm{Hg}(1))=2.991(5) \AA$, ang $(\mathrm{C}(6)-\mathrm{N}(6) \ldots \mathrm{Hg}(1))=128.04(10) \AA$. This behavior is not common and seldom reported [29]. 


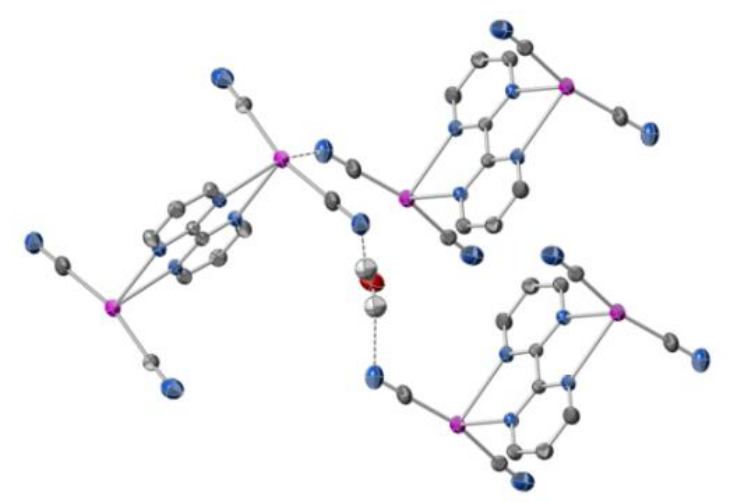

Figure 5. Intermolecular interactions in solid 4. Non fundamental hydrogen atoms are omitted for clarity (ORTEP plot 50\%)

\section{Complex 5}

The structure of 5 shows two non-equivalent mercury atoms, $\mathrm{Hg}(1)$ and $\mathrm{Hg}(2)$, having both characteristic coordination number of four and effective coordination number respectively of 5 and 6 . The former has two strong interactions with the sulfur atoms of the coordinated thiocyanate ligands and with two nitrogen of a bipym (table 2), and a weaker interaction with the nitrogen of a neighbour SCN $(\mathrm{d}(\mathrm{Hg}(1)-\mathrm{N}(31))=2.661(5) \AA) . \mathrm{Hg}(2)$ is similarly involved in four strong interactions with two sulphur atoms and the organic ligand (table 2) and in two weaker interactions with the nitrogen atoms of two close $\operatorname{SCN}(\mathrm{d}(\mathrm{Hg}(2)-\mathrm{N}(11))=3.083(4) \AA, \mathrm{d}(\mathrm{Hg}(2)-\mathrm{N}(21))=2.771(4) \AA)$. The coordination sphere of $\mathrm{Hg}(1)$ forms a trigonal bipyramid $(\tau=1)$ and that of $\mathrm{Hg}(2)$ a distorted octahedron. The two non-equivalent organic ligands are planar and undistorted by the coordination. The four SCN ligands are two bridging and two terminal. This structure allows the propagation of an inorganic chain along the c-axis, that is connected with the nearest chains through two bipym in opposite directions. These ligands spatially form an helix (figure 6), and constitute the organic matrix where the inorganic chains develop. This network defines a 3D coordination polymer, with a series of hollow fishbone-like channels along the $b$ axis where the terminal SCN are positioned. To our knowledge, this is the first 3D polymer built up by the $\mathrm{Hg}(\mathrm{SCN})_{2}$, although the bridging mode of this pseudohalide anion is well reported and many coordination polymers have been synthesized.

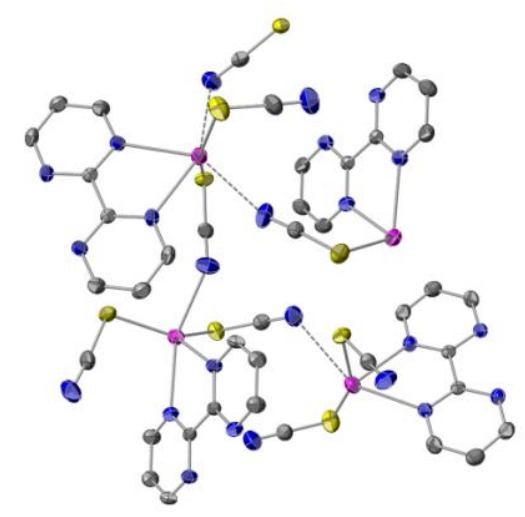

Figure 6. Helical disposition of bipym in 5. Hydrogen atoms are omitted for clarity (ORTEP plot 50\%)

\section{Vibrational analysis}

Vibrational spectra of 1-5 in $4000-400 \mathrm{~cm}^{-1}$ region are largely characterized by the internal modes of bipym ligand. The spectra of $\mathbf{4}$ and $\mathbf{5}$ compounds show also the stretching modes of the CN and SCN ligand respectively. A complete vibrational assignment for 2,2-bipyrimidine has been proposed[30] and recently revised on the basis of DFT computations[31]. A normal coordinate analysis and a DFT based assignment for the coordinated bipym in the $\mathrm{Ru}(\text { bipym })_{3}{ }^{3+}$ complex has been developed[32]. Infrared spectra are usually diagnostic of the coordination mode of the bipym ligand, especially in the $1600-1500 \mathrm{~cm}^{-1}$ region, where appear the ring stretching modes[33]. In this work we have tried an assignment of the vibrational infrared and Raman spectra of 1-5 compounds by comparison with the spectra of the bipym . Results are reported in table S5

\section{$3200-2900 \mathrm{~cm}^{-1}$ region}


In this region the main vibrational modes are $v(\mathrm{CH})$. Crystalline bipym has two molecules in the unit cell, but vibrational spectra show very little coupling, and the reported assignment has been done by considering molecular modes and a planar $\mathrm{D}_{2 \mathrm{~h}}$ symmetry. Six modes are expected, three infrared and three Raman. The main effect of metal coordination to these modes is a mean increment of $35 \mathrm{~cm}^{-1}$, that could be attributed to the charge variation of the $\mathrm{C}-\mathrm{H}$ bond in consequence of the ligand $\rightarrow$ metal electron donation. The variation in the charge distribution along $\mathrm{C}-\mathrm{H}$ bonds is also suggested by the strong decrease of the band intensities of $v(\mathrm{CH})$ in the metal complexes by respect to the free bipym.

\section{$2300-2000 \mathrm{~cm}^{-1}$ region}

In this region are the $\mathrm{C}-\mathrm{N}$ stretching of cyanide groups of 4 . The raman symmetric mode is $2185 \mathrm{~cm}^{-1}$, the infrared asymmetric at $2183 \mathrm{~cm}^{-1}$. The modest coupling between two $v(\mathrm{CN})$ could be attributable to the bending of $\mathrm{C}-\mathrm{Hg}-\mathrm{C}$ angle $\left(164.85(18)^{\circ}\right)$. By respect the $v(\mathrm{CN})$ of $\mathrm{Hg}(\mathrm{CN})_{2}$ in solution[34], is a red shift of $13 \mathrm{~cm}^{-1}$, that can be attributed to the effect of coordinated bipym. In the same spectral region are the $v(\mathrm{C} \equiv \mathrm{N})$ modes of thiocyanide ligand of 4 , that show a raman feature at $2123 \mathrm{~cm}^{-1}$.

\section{$1600-500 \mathrm{~cm}^{-1}$ region}

In this region are found ring stretching modes and $\mathrm{C}-\mathrm{H}$ in-plane and out-of-plane deformation modes. A comparison with the vibrational frequencies of free bipym shows that mercury coordination has a little effect onto the ring modes, apart from a little increment of the frequencies. This upward shift has been also found in 4,4'-bipyridil metal complexes, and has been explained by considering a coupling with low wave number vibrations of metal-ligand bonds[35], especially with metal-nitrogen bonds. This upward shift is more pronounced when bipym is coordinated to lighter metal, as $\mathrm{Cu}, \mathrm{Ni}$ and $\mathrm{Fe}$ $\left[36^{\mathrm{a}-\mathrm{c}}\right]$. Also the pyridine bound to metal atoms shows an upward shift of the vibrational frequencies, that has been interpreted both in term of vibrational coupling with metal-nitrogen bond and of the nature of this bond[37]. The shift is greater when stronger the metal-nitrogen interaction, especially in presence of $\sigma$-donation and $\pi$-back donation interactions. $\mathrm{Hg}(\mathrm{II})$ atom probably behaves as the $\mathrm{Ag}(\mathrm{I})$ cation, where these interactions are weak, and this fact explicates the modest vibrational shift found in 1-5.

\section{Thermal analysis}

We performed a TGA and DSC analysis on the compounds 1, 2, 3, 4 and 5 to study the reticular energy of the supramolecular framework and to investigate the effect of heating on the supramolecular architecture, in order to find if it could be the driving force of a crystalline reorganization with the formation of polymorphs. The DSC pattern of 1 reveals a melting endothermic peak at $145^{\circ}$, with a successive degradation at $200^{\circ}$, confirmed by the TGA analysis. The DTGA shows at least two different reactions that occur at once. The compound 4 shows a more complex pattern: the TGA profile indicates clearly a water loss at $110^{\circ}$, the DSC pattern shows dehydratation at $120^{\circ}$. At higher temperatures, an endothermic peak at $170^{\circ}$, attributable to a melting process. The compound degradation starts at $250^{\circ}$ and a single step is clear, DTGA shows that in this step three reactions occur. The complex $\mathbf{5}$ decomposes before melting at $200^{\circ}$. The decomposition in this case is more complex, with two degradation steps clearly separated and for each one DTGA shows at least two reaction patterns. The compound's melting point suggests that the reticular energy increases moving from 1 to 4, whether $\mathbf{2}, 3$ and 5 decompose before their melting point. The degradations' temperatures indicate stronger reticular interactions in the complexes than that of the ligand itself and a greater stability for the polymers based on the $\mathrm{Cl}$ and $\mathrm{Br}$ than that of I, probably for the structure based on inorganic chain frameworks, and is indicative of the structural isomorphism of 1 and 2 . The pseudohalides are more stable, especially the thiocyanate; this can be explained for the stronger bond in the last case than that for all other counter anions. 

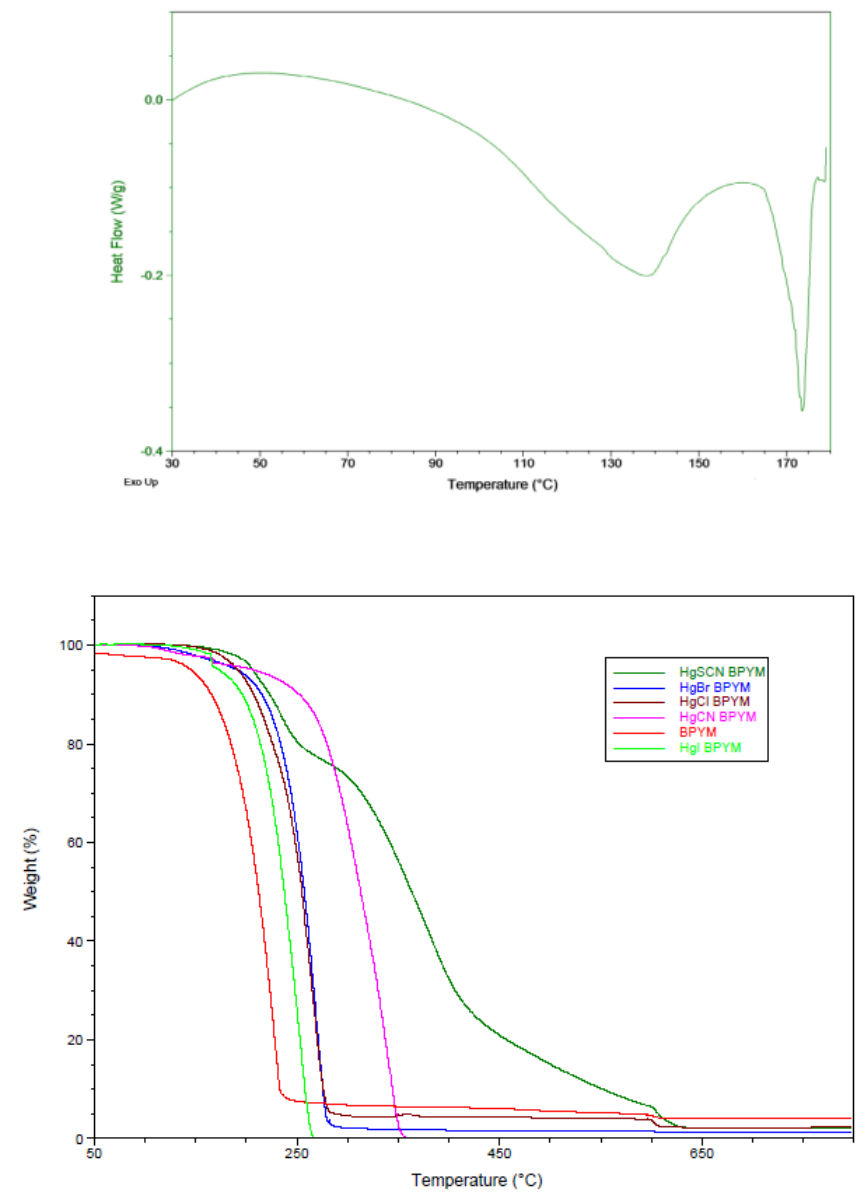

Figure 7. DSC (top) of 4 and TGA (bottom) thermograms of 1-5 compounds

\section{Computational analysis}

In order to evaluate the effect of bipym coordination to $\mathrm{HgX}_{2}$ systems we performed a DFT analysis of model compounds. For complex 1, we calibrated the method on the experimental geometric and spectroscopic (vibrational frequencies) parameters of $\mathrm{HgCl}_{2}$, and found the best parameters with the B3BPW91 hybrid functional with a quasi-relativistic pseudopotential for mercury (see experimental section for details). We started by examining the $\left(\mathrm{HgCl}_{2}\right)_{2}$ dimer. In figure 8 are reported the most interesting results:

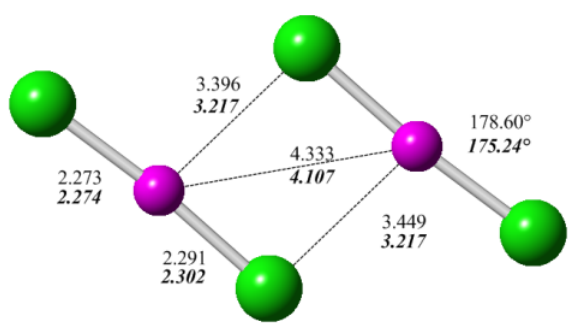

Figure 8. Experimental and computed (italic, bold) geometrical parameters of $2 \mathrm{HgCl}_{2}$ (distances in $\AA$ and angles in degree)

Geometrical parameters are well reproduced, and a NBO analysis gives some interesting informations on the reciprocal effect of $\mathrm{HgCl}_{2}$ units. The computed $\mathrm{Hg}-\mathrm{Cl}$ distance in $\mathrm{HgCl}_{2}$ is $2.273 \AA$ (vs. an experimental gas phase value of 2.252(5) $\AA$ ) [38]; in the dimer we find an elongation of the $\mathrm{Hg}-\mathrm{Cl}$ bond involved in the intermolecular contacts. The charge distribution (figure 9) point out a little bond polarization, and doesn't highlights charge transfer between $\mathrm{HgCl}_{2}$ units. Bond polarization reflects on the $\mathrm{Hg}-\mathrm{Cl}$ bond order (analyzed by means of Wiberg bond order[39]): in $\mathrm{HgCl}_{2}$ is 0.7436 , while in $\left(\mathrm{HgCl}_{2}\right)_{2}$ is 0.6787 for the longer and 0.7706 for the shorter $\mathrm{Hg}-\mathrm{Cl}$ bond. 


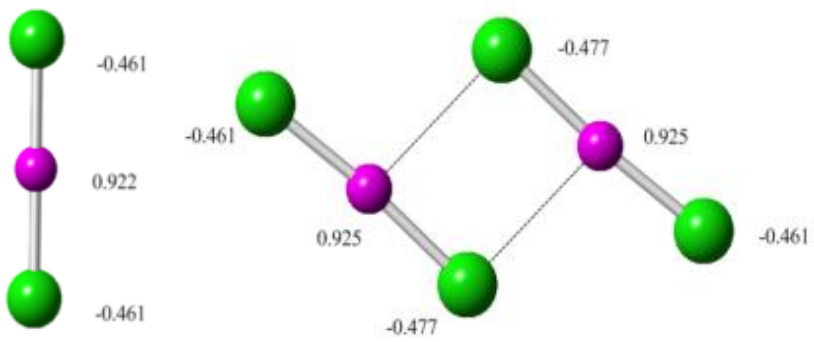

Figure 9. $\mathrm{NBO}$ charge of $\mathrm{HgCl}_{2}$ and $2 \mathrm{HgCl}_{2}$

The effect of bipym on $\mathrm{HgCl}_{2}$ has been evaluated by means of two model compounds, the (bipym) $\left(\mathrm{HgCl}_{2}\right)_{2}$ and his dimer (figure 10). By comparing computed geometrical parameters of $\mathrm{HgCl}_{2}$ and (bipym) $\left(\mathrm{HgCl}_{2}\right)_{2}$, we can see that the coordination of bipym to $\mathrm{HgCl}_{2}$ induces a lengthening of $\mathrm{Hg}-\mathrm{Cl}$ bond and a bending of $\mathrm{Cl}-\mathrm{Hg}-\mathrm{Cl}$ angle higher than those found in $\left(\mathrm{HgCl}_{2}\right)_{2}$.

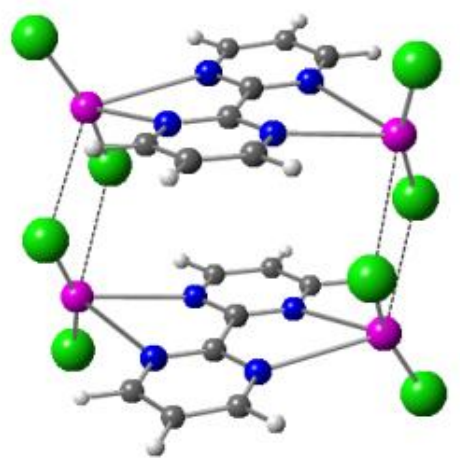

Figure 10. Computed geometry of $\left.\left[(\text { bipym }) \mathrm{HgCl}_{2}\right)_{2}\right]$

The analysis of NBO charge distribution indicates a charge transfer of $0.101 e$ from bipym to $\mathrm{Hg}$; the Wiberg bond index is 0.7230 for $\mathrm{Hg}-\mathrm{Cl}$ and 0.0926 for $\mathrm{Hg} \cdots \mathrm{N}$, while in $\left(\mathrm{HgCl}_{2}\right)_{2}$ is 0.0666 for $\mathrm{Hg} \cdots \mathrm{Cl}$. The donor-acceptor $\mathrm{NBO}$ analysis indicates a modest transfer from LP of chlorine to acceptor orbitals of $\mathrm{Hg}(7.80 \mathrm{kcal} / \mathrm{mol})$, whilst in 2,2-bipyrimidine the donor-acceptor interaction from LP of nitrogen and empty orbitals of mercury involves an energy of $12.0 \mathrm{kcal} / \mathrm{mol}$. The $\left(\mathrm{HgCl}_{2}\right)_{2}$ unit computed in the system [bipym $\left.\left(\mathrm{HgCl}_{2}\right)_{2}\right]_{2}$ has $\mathrm{Hg}-\mathrm{Cl}$ distances similar to the experimental found in $\mathbf{1}$, slightly greater than those computed for $\left(\mathrm{HgCl}_{2}\right)_{2}$ system and similar to that computed for (bipym) $\left(\mathrm{HgCl}_{2}\right)_{2}$. Also the $\mathrm{Cl}-\mathrm{Hg}-\mathrm{Cl}$ angle is similar to that of the monomer, but wider than that found in $\mathbf{1}$. By considering that $\mathrm{Hg} \cdots \mathrm{Cl}$ intermolecular interactions have little effect on Cl-Hg-Cl angle, as seen in the $\left(\mathrm{HgCl}_{2}\right)_{2}$ system, the main effect is attributable to nitrogenmercury interaction: 1 has a shorter $\mathrm{N}-\mathrm{Hg}$ distance than that computed for (bipym) $\left(\mathrm{HgCl}_{2}\right)_{2}$ and his dimer, and this could influence the $\mathrm{Cl}-\mathrm{Hg}-\mathrm{Cl}$ angle. Apart a greater bipym-bipym distance the $\left[(\text { bipym })\left(\mathrm{HgCl}_{2}\right)_{2}\right]_{2}$ model shows that the dimeric $\left(\mathrm{HgCl}_{2}\right)_{2}$ fragment is retained and that bipym- $\mathrm{HgCl}_{2}$ interaction is not different to that of monomer, as shown by the analogous charge transfer of $0.100 e$ from bipym to $\mathrm{HgCl}_{2}$ unit.

We performed a DFT modeling for the iodide complex 3. As in the study of 1 we calibrated the choice of basis set on $\mathrm{HgI}_{2}$, and the computed $\mathrm{Hg}$-I distance and vibrational frequencies are in reasonable accord with the experimental ones [40] $\left(2.593 \AA ; 226,152,51 \mathrm{~cm}^{-1}\right.$ vs. $\left.2.553(2) \AA ; 235,156,49 \mathrm{~cm}^{-1}\right)$.
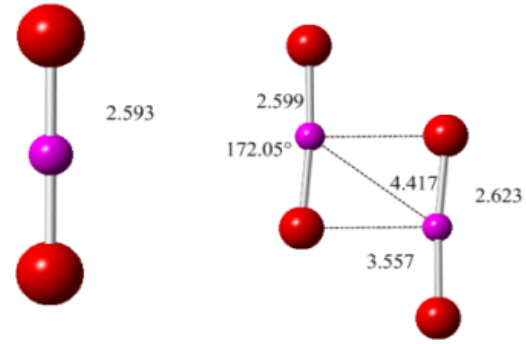

Figure 11. Computed geometry of $\mathrm{HgI}_{2}$ and of $\left(\mathrm{HgI}_{2}\right)_{2}$ (distances in $\AA$ and angles in degree) 
A DFT modeling of $\left(\mathrm{HgI}_{2}\right)_{2}$ shows that this fragment is substantially maintained in $\mathbf{3}$, apart some geometry variations, similar to those found in complex 1, due to the nitrogen-mercury interaction of bipym (figure 11): a little lengthening of $\mathrm{Hg}-\mathrm{I}$ bond and a bending of I-Hg-I angle. A significant difference of the iodine model by respect the chlorine model is that the computed $\mathrm{Hg} \cdots \mathrm{I}$ intermolecular distance is greater than the experimental, the opposite of that found in $\left(\mathrm{HgCl}_{2}\right)_{2} \mathrm{system}$ A guess to the charge distribution shows that in the $\mathrm{HgI}_{2}$ molecule there is a reduction of the bond charge separation by respect to $\mathrm{HgCl}_{2}$, but experimental $\mathrm{Hg} \cdots \mathrm{Hg}$ distance is lesser in 3 than in $\mathbf{1}$ (4.265(1) $\AA$ vs 4.333(1) $\mathrm{A}$ ). We can suppose that the reduction of electrostatic interactions in $\mathrm{HgI}_{2}$ dimers are compensated by the most significant dispersion forces, not well represented in our computational method. A computation of $\left(\mathrm{HgI}_{2}\right)_{2}$ dimer with inclusion of Grimme's B97-D dispersion term gives a $\mathrm{Hg} \cdots \mathrm{Hg}$ distance of $4.291 \AA$, very similar to the experimental value in $\mathbf{3}$, nevertheless the $\mathrm{I} \cdots \mathrm{Hg}$ intermolecular distance is overvalued, at $3.667 \AA$.
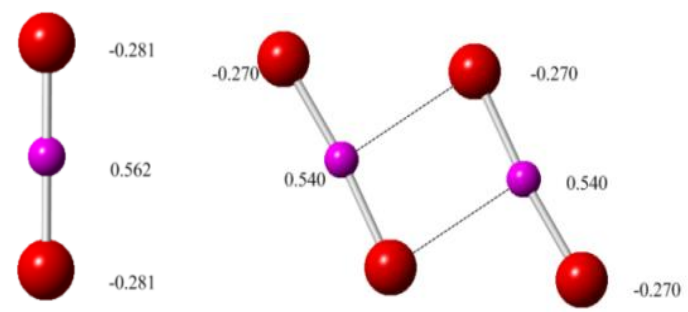

Figure 12. $\mathrm{NBO}$ charges of $\mathrm{HgI}_{2}$ and $\left(\mathrm{HgI}_{2}\right)_{2}$

\section{Electronic spectra}

Because the extreme low solubility of 1-5 complexes, we recorded UV-VIS spectra only in the solid state (Figure 13) All spectra show a common intense band in the UV region at ca. $235 \mathrm{~nm}$, and two broader features in the 250-400 nm interval. According to his electron structure $\left[41^{\mathrm{a}-\mathrm{b}}\right]$, the strongest higher energy part of bipym spectrum is attributable to $\pi \rightarrow \pi^{*}$ transitions, while the broader feature at longer wavelength are usually assigned to $n \rightarrow \pi^{*}$ transitions [41b]. The complexation of bipym to $\mathrm{HgX}_{2}$ affects the energy of $\mathrm{N}$ lone pairs, and this can explain the changes in the 250-400 $\mathrm{nm}$ region. In order to evaluate these effects we computed the electronic transitions on optimized geometry by means of a configuration interaction Hartree-Fock with double correction (CIS(D)) method both for bipym and 1-5 complexes. The optimized geometry of bipym is $\mathrm{D}_{2 \mathrm{~h}}$, meanwhile that of $\mathbf{1 - 5}$ complexes is $\mathrm{C}_{2 \mathrm{~h}}$. Most significant results and spectral attributions are summarized in table S6. The analysis of MO composition show that the high energy transition is mainly $\pi \rightarrow \pi^{*}$ of bipym ligand, and is scarcely affected by the $\mathrm{Hg}$ (II) coordination. In 1-3 complexes the transition at higher wavelength show an increasing halogen $\rightarrow \mathrm{Hg}$ charge transfer on passing from $\mathrm{Cl}$ to $\mathrm{I}$. In $\mathbf{4}$ and $\mathbf{5}$ the 250-400 $\mathrm{nm}$ region contain both $\mathrm{n} \rightarrow \pi^{*}$ and $\mathrm{CN}$ (or SCN) $\rightarrow \mathrm{Hg}$ transitions. Nevertheless, the interpretation of electronic spectra based only on an insulated molecule model could be too approximate to analyze the electron transitions of polymeric coordination complexes. Actually, solid bipym has a broad weak features spanned from 380 to $600 \mathrm{~nm}$, responsible of the reddish color of the solid phase, not found in the solution spectra. These transitions are probably attributable to intermolecular charge transfer in the crystalline state, favored by $\pi-\pi$ staking. Complexes $\mathbf{1}$ and $\mathbf{3}$, where this interaction is stronger, show similar bands around $500 \mathrm{~nm}$; whereas in complexes 2 and $\mathbf{4}$ these features are lesser. The strong band at $370 \mathrm{~nm}$ could be attributed to a ligand-to-ligand transition, similarly to that found in the polymeric $\left(\mathrm{HgI}_{2}\right)_{2}\left(4,4^{\prime}\right.$-bipy $)$ [42]. In order to evaluate the electronic transition in the solid state, we examined the total density of states (DOS) derived from the band structure of crystalline solid (obtained from a single point energy computation of the experimental geometry). In Figure 13 we report the DOS and band structure of complex $\mathbf{1}$ and $\mathbf{3}$, computed in the first Brillouin zone path (described in figure S6). In 1 the electron transitions from the top valence band to the bottom conduction band involve mainly $\mathrm{C}$ and $\mathrm{N}$ atoms, and are therefore interpretable as $\pi \rightarrow \pi^{*}$ and $n \rightarrow \pi^{*}$. For the complex 3 the DOS analysis highlights that the top valence band has a main contribution from iodine atoms, and the bottom conduction band involves mainly the nitrogen atoms. The electron transitions from these bands in crystalline $\mathbf{3}$ are therefore attributable to interligand excitations, and can explain the strong absorption at $370 \mathrm{~nm}$.. 


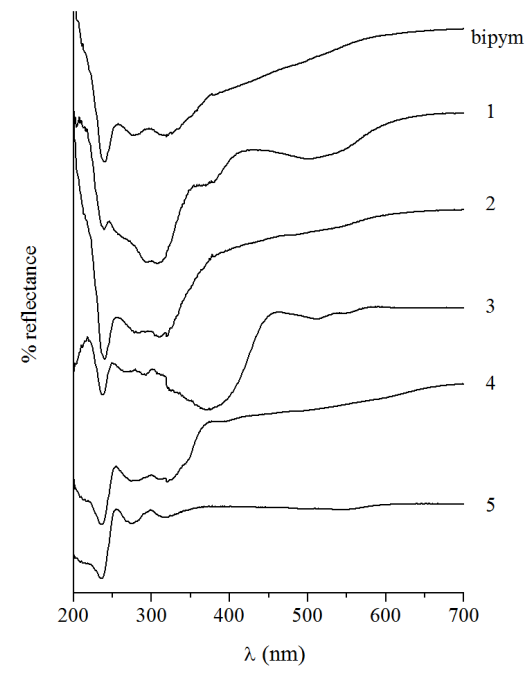

Figure 13. UV-VIS reflectance spectra of bipym and 1-5 complexes

All 1-5 complexes are luminescent, and by excitation at $315 \mathrm{~nm}$ show two emissions at ca. 460 and $560 \mathrm{~nm}$ (figure S8). The bipym has an emission at $574 \mathrm{~nm}$, with a relevant stock shift by respect the emission found in solution [43], where a fluorescence emission has been found at $350 \mathrm{~nm}$ by exciting at $320 \mathrm{~nm}$. The stock shift could be explained by the relevant $\pi-\pi$ staking interactions in the crystalline state. The emission in the complexes can be attributed to $n \rightarrow \pi *$ transition, and the scarce variability in the wavelength is imputable to the modest perturbation induced in the bipym as consequence of the coordination. The photoluminescence properties of $\mathrm{d}^{10} \mathrm{Hg}(\mathrm{II})$ complexes are usually attributed to ligand centered transitions [44], and $\mathrm{Hg}$ (II) acts mainly as stabilizer of the ligand, reducing the non radiative decay.
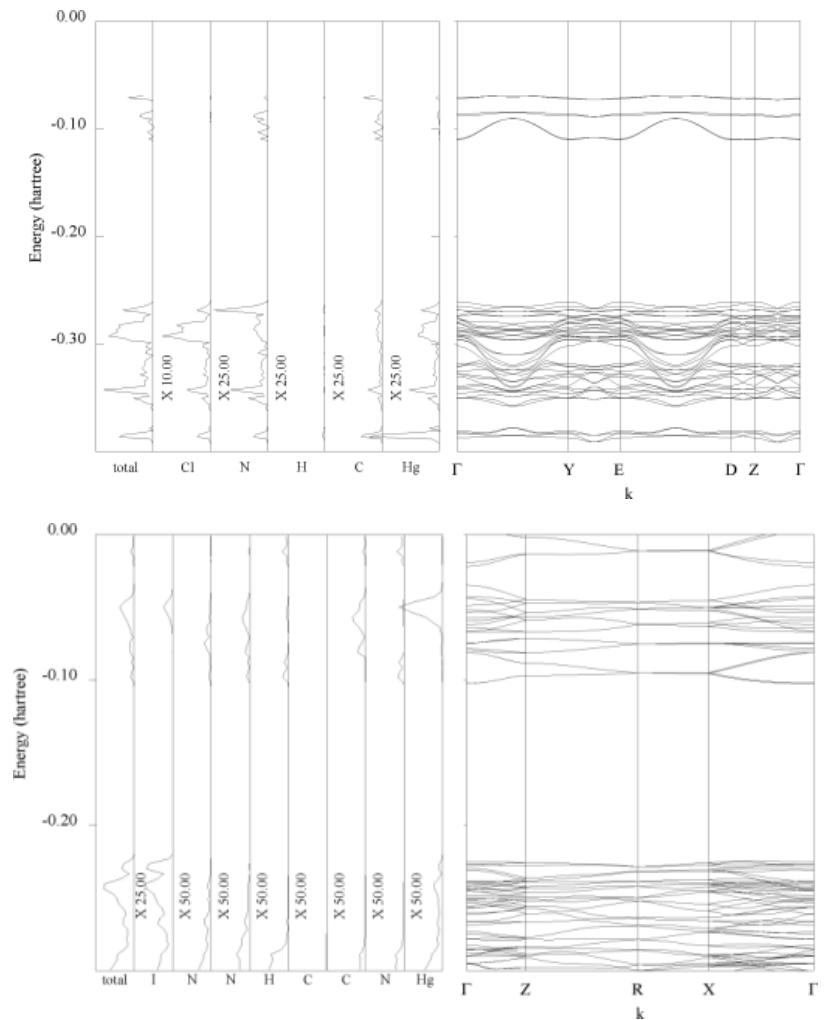

Figure 14. Band structure and DOS of complex 1 (top) and 3 (bottom) 


\section{Discussion}

We prepared five bipym derivatives of $\mathrm{HgX}_{2}$ with a differing synthetic approach by respect that used by Lanza and Jarabat $^{5}$. They obtained the products in form of a precipitate by mixing solutions of the reagents, whereas we used the ability of acetonitrile to dissolve, by heating and mixing, the precipitate that is obtained. From the orange solution formed is easy to grow single crystals by evaporation.

Compound 1 is a $1 \mathrm{D}$ polymer obtained by insertion of bipym in two columns formed by polymerization of $\left(\mathrm{HgCl}_{2}\right)_{2}$ units. The coordination of bipym to $\mathrm{HgCl}_{2}$ induces some geometrical changes: an elongation of $\mathrm{Hg}-\mathrm{Cl}$ bond and a bending of $\mathrm{Cl}-$ $\mathrm{Hg}-\mathrm{Cl}$ angle, while bipym geometrical parameters are substantially unchanged. This is in accord with the modest vibrational variation of the ring modes in coordinated bipym and with our computational model that show very low $\mathrm{Hg}-\mathrm{N}$ bond order. The weakness of bipym-Hg interactions is a consequence of the low Lewis basicity of bipym. Mean $\mathrm{Hg}-\mathrm{N}$ distance is $2.596 \AA$; a comparison with the $\mathrm{RR}^{\prime}$ bipym $\mathrm{HgCl}_{2}[45]$ with a mean $\mathrm{d}(\mathrm{Hg}-\mathrm{N})=2.316(8) \AA$ and with bipyHgCl ${ }_{2}[46]$ where $\mathrm{d}(\mathrm{Hg}-\mathrm{N})=2.393(1) \AA$ shows a stronger interaction of these last. However, there are evidences of a charge transfer from the organic ligand to the mercury both from the evaluation of infrared intensities of $\mathrm{C}-\mathrm{H}$ stretching modes and from the computational model. However, the aromatic system doesn't seem significantly perturbed, as suggested by the small

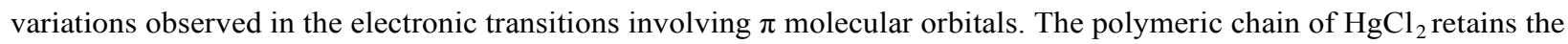
geometry arrangement of crystalline $\mathrm{Hg}(\mathrm{II})$ chloride, with rows of slipped $\mathrm{HgCl}_{2}$ units (see figure 2). This disposition has been explained in term of electrostatic interactions [47]. A seminal work of Kaupp and Schnering[21] showed the importance of relativistic effect in the halogen-mercury bond and his influence in the reduction of electrostatic interactions in the $\mathrm{Hg}$-X bonds, and showed that the $\mathrm{C}_{2 \mathrm{~h}}$ arrangement of $\left(\mathrm{HgCl}_{2}\right)_{2}$ units is a minimum. They computed also the dimerization energy for $\mathrm{HgCl}_{2}$ and found a modest value of $24.3 \mathrm{KJ} / \mathrm{mol}$ (MP2, counterpoise corrected); this value underlines the weak intermolecular interactions in crystalline $\mathrm{HgCl}_{2}$, as also evidenced by the weak sublimation enthalpy of $77.4 \mathrm{~kJ} / \mathrm{mol}[21]$. The fragment $\left(\mathrm{HgCl}_{2}\right)_{2}$ has a bent $\mathrm{Cl}-\mathrm{Hg}-\mathrm{Cl}$ angle, both in crystalline state than in the computed model. The bending of X-Hg-X angle depends on intermolecular interactions of $\mathrm{Hg}$ [48] and the modest effect of intermolecular $\mathrm{Hg} \cdots \mathrm{Cl}$ interactions (the $\mathrm{NBO}$ charge of $\mathrm{Hg}$ varies from 0.922 in $\mathrm{HgCl}_{2}$ to 0.925 in $\left(\mathrm{HgCl}_{2}\right)_{2}$ ) could explicate the little variation of $\mathrm{Cl}-\mathrm{Hg}-\mathrm{Cl}$ angle. In figure $\mathrm{S} 9$ it can be seen the distribution of the experimental distances and angles obtained from the CSD database searching for the lozenge shaped $\left(\mathrm{HgCl}_{2}\right)_{2}$ dimer. The histograms show a maximum at $3.250 \AA$ for $\mathrm{Hg} \cdots \mathrm{Cl}$, and $88^{\circ}$ for the $\mathrm{Cl}-\mathrm{Hg}-\mathrm{Cl}$ and $95^{\circ}$ for $\mathrm{Hg}-\mathrm{Cl}-\mathrm{Hg}$. These data are in good agreement with the DFT results before reported. However, the tendency of this salt to form inorganic chains, in spite of the weakness of the involved interactions, could explain the ladder form of this $1 \mathrm{D}$ coordination polymer. This topology is rare in the chemistry of bipym ligand[23] ${ }^{\text {Errore. Il segnalibro non è definito. }}$, and the constrain induced by the $\mathrm{HgCl}_{2}$ polymerization could make favorable the $\pi-\pi$ stacking interactions. Compound $\mathbf{2}$ has a crystalline architecture substantially analogous to $\mathbf{1}$, with minor differences due to bigger dimension of bromine by respect to chlorine. Reported structures are not enough to allow a statistical analysis and it could be noticed a minor tendency to build up coordination polymers.

A different behavior is found in complex 3: it's describable as a ribbon of alternating $\left(\mathrm{HgI}_{2}\right)_{2}$ dimers in a quasi- $\mathrm{C}_{2 \mathrm{~h}}$ symmetry and bipym units. The $\left(\mathrm{HgI}_{2}\right)_{2}$ fragment is not found in crystalline polymorphs of $\mathrm{HgI}_{2}$, where tetrahedral and octahedral iodine coordination is preferred, and is reported in some coordination polymers of pyrazine derivatives[49]. The search of the CSD database for the lozenge shaped $\left(\mathrm{HgI}_{2}\right)_{2}$ fragment point out a less tendency of $\mathrm{HgI}_{2}$ to generate this topology and to form polymeric chains, and by respect $\mathrm{HgCl}_{2}$ and $\mathrm{HgBr}_{2}$ the presence of stronger $\mathrm{Hg} \cdots \mathrm{I}$ interactions (figure S10).

From the statistical analysis of structures reported in the CSD database (Table 3), there seems to be indication of a general behavior: 1) on moving from chlorine to iodine there is a minor tendency to form coordination polymers 2 ) at the same time it's possible to notice a decrease of the tendency to generate a lozenge shaped topology based on weak non-bonding interactions that expand the effective coordination number of the $\mathrm{Hg}$ (II).

\begin{tabular}{|c|c|c|c|}
\hline Fragment & $\begin{array}{c}\text { Total } \\
\text { structures }\end{array}$ & Polymers & $\begin{array}{c}\text { Weak bridging non } \\
\text { bonded interactions }\end{array}$ \\
\hline $\mathrm{HgCl} 2$ & 1052 & $325(31 \%)$ & $195(19 \%)$ \\
\hline $\mathrm{HgBr} 2$ & 489 & $141(29 \%)$ & $44(9 \%)$ \\
\hline $\mathrm{HgI} 2$ & 586 & $160(27 \%)$ & $14(3 \%)$ \\
\hline
\end{tabular}

Table 3. Polymeric structure obtained from $\mathrm{HgX}_{2}$ unit and weak halogen-mercury bridging interactions $(\mathrm{R}(\mathrm{Hg} \ldots \mathrm{X})<\operatorname{sum}$ of $\mathrm{VdW}$ radii) reported in the CSD (2015) database. Most of coordination polymers containing $\mathrm{HgI}_{2}$ unit propagate through organic ligand

This affects the topology of $\mathbf{1}, \mathbf{2}$ and $\mathbf{3}$ coordination polymers: $\mathbf{1}$ and $\mathbf{2}$ have a ladder-like chain expansion, while $\mathbf{3}$ shows a ribbon type polymerization with the lack of $\pi-\pi$ interactions between the aromatic rings. 
Few compound of $\mathrm{Hg}(\mathrm{CN})_{2}$ coordinated to other N-ligands have been reported, and only four with heterocyclic compound[50]. The interaction of $\mathrm{Hg}(\mathrm{CN})_{2}$ with bipym in 4 doesn't induce strong bond variations, apart the bending of C$\mathrm{Hg}-\mathrm{C}$ angle and a modest lengthening of $\mathrm{C}-\mathrm{Hg}$ and $\mathrm{C}-\mathrm{N}$ bonds, (responsible of the red-shift of $\mathrm{n}(\mathrm{CN}$ ) from 2197 to 2177 $\mathrm{cm}-1$ [34]). The N-Hg mean distance of $2.64 \AA$ is higher than that in 4,4'-bipyridine adduct[42] (2.449(5) $\AA$ ), and this confirms the weaker Lewis base behaviour of bipym. The geometric requirement of $\mathrm{CN}$ ligand to form bridging connection with a quasi-linear arrangement of $\mathrm{M}-\mathrm{CN}-\mathrm{M}$, and the steric hindrance of (bipym) $\mathrm{Hg}(\mathrm{CN})_{2}$ unit probably make less favourite the formation of polymeric structure with the cyanide ligand, by respect to the halogens.

The crystal structure of compound $\mathbf{5}$ confirms the well documented [52] tendency of SCN ligand to form coordination polymers with $\mathrm{Hg}(\mathrm{II})$, and this is made easier by the stronger ambidentate nature of SCN by respect the other anions investigated in this study. This is evidenced by TGA data, that reports a decomposition temperature of $\mathbf{5}$ higher than that found in 1-4. However, bidentate ancillary ligands with $\mathrm{Hg}(\mathrm{SCN})_{2}$ have been seldom reported, and usually coordination polymers of $\mathrm{Hg}(\mathrm{SCN})_{2}$ present $1 \mathrm{D}$ and $2 \mathrm{D}$ architectures. In the case of the complex with the 2,2'-bipyrimidine, a 3D structure is formed, where the inorganic framework is maintained, and the organic ligand act as a "propagator" that allows the connection with other chains. This crystalline architecture is representative of the importance of a selective choice of the organic ligand to lead the dimensionality of the final product.

\section{Conclusions}

In this work we have studied the crystal engineering versatility of a k-N bidentate organic ligand, the 2,2'-bipirymidine, with some typical $\mathrm{d}^{10}$ building blocks like the halides and pseudohalides of $\mathrm{Hg}$ (II). We have performed a structural characterization of the complexes, by means of single crystal XRD methods, computational, spectroscopic and thermal analysis, with a special attention to the analysis of the subtle compensation of forces typical in the chemistry of mercury complexes. The overall results are quite interesting for a deeper comprehension of the behaviour of the bipym, and for the comprehension of the strength of the interactions in the organometallic derivatives of mercury salts. It is possible to deduce that in the reported complexes the interactions between the 2,2'-bipyrimidine and $\mathrm{Hg}$ (II) are quite weak, as demonstrated by the little structural effects of the metal coordination and by the vibrational spectra. The thermal behaviour of the complexes shows the stronger interactions in the thiocyanate, the only example of a clearly bidentate anion, and weaker forces in the other compounds. On the other hand, it is clear that the tendency of the halide anions to bridge and to form weak-bonded dimers, is a strong driving force in the formation of the coordination polymers and is responsible of the mayor structural variations in the coordination sphere of the mercury. We are able to rationalize the behaviour of the different halides through a computational and a statistical analysis of literature data. With heavier halide we noticed a less tendency to form coordination polymers in. The role of the bidentate ligand to maximise the dimensionality of the supramolecular structure is relevant, and permits the formation of 1D and 3D coordination polymers. The electronic and photoluminescence properties of the bipym complexes have been investigated and analysed by using molecular and solid state periodic computational modelling. This approach shows the increasing contribution of the halide to the main electron excitation on passing from the chlorine to the iodine and it can be noticed that the insulated molecule modelling isn't always the optimal choice to interpret solid state photoluminescence properties. A knowledge of the band structure and exciton's transmission through $\pi-\pi$ stacking and are fundamentals for the correct interpretation of electronic transition in organometallic compounds analysed in solid state, especially coordination compounds that hasn't intrinsically a molecular OD-nature.

\section{Acknowledgements}

The authors are grateful to prof. Giuliana Gervasio for her precious aid in the crystal structure determination and for her suggestions.

\section{AUTHOR INFORMATION}

\section{Corresponding Author}

Eliano Diana, Dipartimento di Chimica, Università di Torino, via P. Giuria 7, 10125 Torino, Italy;

e-mail: eliano.diana@unito.it; tel.+39 011 6707572; fax +390116707855 


\section{REFERENCES}

[1] Steed J. W., Atwood J. L., Supramolecular Chemistry, VCH, New York, 2000; (a) Holliday B. J., Mirkin C. A., Angew. Chem. Int. Ed. , 4 (2001) 2022-2043; (b) Carlucci L., Ciani G., Proserpio D. M., Coord. Chem. Rev, 246 (2003) 247-289; (c) Sweigers G. F, Malefeste T. J., Chem. ReV. 100 (2000) 3483-3537; (d) Leinninger S., Olenyuk B., Stang P. J., Chem. Rev. 100 (2000) 853-907; (e) Beatty A. M., Coord. Chem. Rev. 246 (2003) 131-143; (f) Roesky H. W., Andruh M., Coord. Chem. Rev. 236 (2003) 91-119; (g) Mamula O., Von Zelewsky A., Coord. Chem. Rev, 242 (2003) 87-95; (h) Ward M. D., McCleverty J. A., Jeffery J. C., Coord. Chem. Rev., 222 (200) 251-272; (i) Kaes C., Katz A., Hosseini M. W., Chem. Rev, 100 (2000) 3553-3590; (j) James S. L., Chem. Soc. Rev. (2003) 276-288; (k) Khlobystov A. N., Blake A. J., Champness N. R.,. Lemenovskii D. A, Majouga A. G., Zyk N. V., Schröder M., Coord. Chem. Rev., 222 (2001) 155-192; (1) Batten S., Robson R., Angew. Chem., Int. Ed., 37 (1998) $1460-1494$.

[2] (a) Kolb A., Bissiier P., Schmidbaur H., Inorg. Chem., 32 (1993) 5132-5135; (b) Schmidbaur H., Graf W., Müller G., Angew. Chem. Int., Ed. Engl. 27 (1988) 417-419; (c) Schmidbaur H., Angew. Chem. Int., Ed. Engl,. 15 (1976) 728-740; (d). White-Morris R. L, Olmstead M. M., Attar S., Balch A. L., Inorg. Chem., 44 (2005) 5021-5029; (e). White-Morris R. L, Olmstead M. M ., Balch A. L., J. Am. Chem. Soc., 125 (2003) 1033-1040; (f). White-Morris R. L,. Olmstead M. M, Balch A. L., Elbjeirami O.,Omary M. A, Inorg. Chem., 42 (2003) 6741-6748; (g).White-Morris R. L,. Stender M, Tinti D. S., Balch A. L., Rios D., Attar S., Inorg. Chem,. 42 (2003) 3237-3244; (h) Hayashi A., Olmstead M. M., Attar S., Balch A. L., J. Am. Chem. Soc., 124 (2002) 5791-5795; (i). WhiteMorris R. L, Olmstead M. M., Jiang F., Tinti D. S., Balch A. L., J. Am. Chem. Soc., 2000, 124, 2327-2336; (j) Eisler D. J., Puddephatt R., Cryst. Growth Des., 5 (2005) 57-59; (k) McArdle C. P., Van S., Jennings M. C., Puddephatt R. J., J. Am.Chem. Soc., 124 (2002) 3959-3965; (1) Brandys M.-C., Puddephatt R. J., Am. Chem. Soc., 124 (2002) 3946-3950; (m) Hunks W. J., Jennings M. C.,. Puddephatt R. J, Inorg. Chem., 39 (2000) 2699-2702; (n) MacDonald M.-A, Puddephatt R. J., Yap G. P. A., Organometallics, 19 (2000) 2194-2199; (o) Yeh T.-T., Wu J.-Y., Wen Y.-S., Liu Y. H., Twu J., Tao Y,-T., Lu K.-L., Dalton Trans., (2005) 656-658; (p). Hannon M. J,. Painting C L., Plummer E. A., Childs L. J., Alcock N. W., Chem. Eur. J., 8 (2002) $2225-$ 2238; (q) Lee K. M ., Wang H. M. J., Lin I J. B, J. Chem.Soc., Dalton Trans,. (2002) 2852-2855; (r) Yang S.-P., Chen X.-M., Ji L.N., J. Chem. Soc., Dalton Trans., (2000) 2337-2343. (s) Chen J.-X., Zhang W.-H., Tang X.-Y., Ren Z.-G., Li H.-X., Zhang Y., Lang J.-P., Inorg. Chem,. 45 (2006) 7671-7680; (t) Lee Y.-A, McGarrah J. E., Lachicotte R. J., Eisenberg R., J. Am. Chem. Soc. 124 (2002) 10662-10663; (u) Chen J.-X., Zhang W.-H., Tang X.-Y., Ren Z.-G Zhang. Y., Lang J.-P., Inorg. Chem., 45 (2006) $2568-$ 2580; (v) Patel U., Singh H. B., Wolmershäuser G., Angew. Chem., Int. Ed., 44 (2005) 1715-1717; (z) Zhang X., Xie Y., Yu W., Zhao Q., Jiang M., Tian Y., Inorg. Chem., 42 (2003) 3734-3737.

[3](a) Raehm L., Mimassi L., Guyard-Duhayon C., Amouri H., Inorg.Chem., 42 (2003) 5654-5659; (b) Sailaja S.,. Rajasekharan M. V, Inorg. Chem., 42 (2003) 5675-5684; (c) Bhogala B. R., Thallapally P. K., Nangia A., Cryst. Growth Des., 4 (2004) 215-218; (d) Tong M.-L., Wu Y.-M., Ru J., Chen X.-M, Chang H.-C., Kitagawa S., Inorg. Chem., 41 (2002) 4846-4848; (e) Qin Z., Jennings M. C., Puddephatt R. J., Inorg. Chem. 41 (2002) 5174-5186; (f) Brammer L., Rivas J. C. M., Atencio R., Fang S., Pigge F. C. B.,, J. Chem. Soc., Dalton Trans., (2000) 3855-3867; (g) Beatty A. M., K., Lorimer R., J. Chem. Soc., Dalton Trans., (2000), 3869-3872; (h) MacDonald J. C., Dorrestein P. C., Pilley M. M., Foote M. M., Lundburg J. L., Henning R. W., Schultz A. J., Manson J. L., J. Am. Chem. Soc., (2000), 11692-11702.

[4](a) Hu C., Kalf I., Englert U., Cryst. Eng. Comm., 9 (2007) 603-610; (b). Khavasi H.R, Tehrani A.A., Inorg. Chem., 52 (2013) 2891-2905; (c) Mahmoudi G., Morsali A., Cryst. Eng. Comm,. , 9 (2007) 1062-1072; (d) Khavasi H. R., Tahrani A.A., Cryst. Eng. Comm., 15 (2013) 5799-5812; (e) Khavasi H.R., Salimi A.R., Eshtiagh-Hosseini H., Amini, Cryst.Eng. Comm., 13 (2011) 37103717 .

[5] (a) Lanza S., Inorg. Chim. Acta, 75 (1983) 131-133; (b) Jaradat Q., Barqawi K. M.M, Akasheh T.S. , Inorg chim acta, 116 (1986) 63-73; (c). Schöberl U, Magnera T.F., Harrison R.M., Fleischer F., Pflug J.L., Schwab P.F.H., Meng X., Lipiak D., Noll B.C., Allured V.S., Rudalevige T., Lee S., Michl J., J. Am. Chem. Soc., 119 (1997) 3907-3917; (d) Lanza S., Rotondo E., Inorg. Chim. Acta, 146 (1988) 205-208.

[6] (a) Khavasi H.R., Barforuosh M.M., Fard M.A., Cryst Eng Comm, 14 (2012) 7236-7244; (b). Baul T.S.B, Kundu S., Mitra S., Höpfl H., Dalton Trans, 42 (2013) 1905-1920; (c) Carnes E.M., Lindquist N.R., Zakharov L.N., Johnson D., Cryst. Growth Des, 12 (2012) 1579-1585; (d). Wang X.F, Lv Y., Okamura T., Kawaguchi H., Wu G., Sun W.Y., Ueyama N. C., Cryst. Growth Des, 7 (2007)1125-1133; (e) Eisler D.J., Puddephat R.J., Dalton Trans, (2003) 3567-3573.

[7] (a) Kaim W., Kohlmann S., Lees A. J., Snoeck T. L., Stufkens D. J.,. Zulu M. M, Inorg. Chim. Acta, 210 (1993) 159-165; (b) Kaim W., Inorg.Chem., 23 (1984) 3365-3370; (c) Dodsworth E. S., Lever A. B. P, Coord.Chem. Rev., 97 (1990) 271-284; (d) Kaim W., Kohlmann S., Inorg. Chem., 2 (1986) 3306-3310.

[8] Liu D.Q., Wang R., Wang S., Dalton Trans., (2004) 2073-2079.

[9] Barquìn M., Garmendia M.J.G., Bellido V., Transition Metal Chem. , 24 (1999) 546-552. 
[10] Sieger M., Vogler C., Klein A., Knodler A., Wanner M., Fiedler J., Za'lis`` S., Snoeck T.L., Kaim W., Inorg. Chem, 44 (2005) 4637-4643; (b) Linfoot C. L., Richardson P., Hewat T.E., Moudam O., Forde M. M., Collins A., White F., Robertson N., Dalton Trans., 39 (2010) 8945-8956.

[11] Agilent Technologies UK Ltd., Oxford, U.K.

[12] Agilent Technologies (20129. CrysAlisProSoftare system, version 1.171.35.11, Agilent Technologies U K Ltd., Oxford, U.K.

[13] Sheldrick, G.M., SHELX97:Program for Crystal Structure Solution and Refinement; University of Göttingen: Göttingen, Germany, 2004

[14] CrystalMaker Software Ltd, Oxford, England (www.crystalmaker.com).

[15] Gaussian 09, Revision C.01, M. J. Frisch, T G. Wrucks, H. B. Schlegel, G. E. Scuseria, M. A. Robb, J. R. Cheeseman, G. Scalmani, V. Barone, B. Mennucci, G. A. Petersson, H.Nakatsuji, M.Caricato, X. Li, H. P. Hratchian, A. F. Izmaylov, J. Bloino, G. Zheng, J. L. Sonnenberg, M. Hada, M. Ehara, K.Toyota, R. Fukuda, J. Hasegawa, M. Ishida, T. Nakajima, Y.Honda, O. Kitao, H. Nakai, T. Vreven, J. A. Montgomery Jr, J. E Peralta, F Ogliaro, M. Bearpark, , J. J. Heyd, E. Brothers, K. N. Kudin, V. N. Staroverov, R. Kobayashi, J. Normand, K. Raghavachari, A. Rendell, J. C. Burant, S. S. Iyengar, J.Tomasi, M. Cossi, N. Rega, J. M. Millam, , M. Klene, J. E. Knox, J. B. Cross, V. Bakken, C. Adamo, J. Jaramillo, R. Gomperts, R. E.Stratmann, O. Yazyev, A. J. Austin, R. Cammi, C. Pomelli, J. W. Ochterski, R. L. Martin, K. Morokuma, V. G. Zakrzewski, G. A Voth, P. Salvador, J. J. Dannenberg, S. Dapprich, A. D. Daniels, Ö. Farkas, J. B. Foresman, , J. V. Ortiz, J. Cioslowski and D. J. Fox, Gaussian, Inc., Wallingford CT, 2009.

[16] Andrae D., Haeussermann U., Dolg M., Stoll H., Preuss H., Theor. Chim. Acta, 77 (1990) 123-141.

[17] Bergner A., Dolg M., Kuechle W., Stoll H., Preuss H., Mol. Phys., 80 (1993) 1431-1441.

[18] Martin J.M.L., Sundermann A., J. Chem. Phys., 114 (2001) 3408-3420.

[19] Dovesi R., Saunders V. R., Roetti C., Orlando R., Zicovich,. Wilson C. M, Pascale F., Civalleri B., Doll K., Harrison N. M., Bush I. J., D'Arco P.and Llunell M., CRYSTAL09, (2009) CRYSTAL09 User's Manual. University of Torino, Torino.

[20] Grdenić D., Rev. Chem. Soc. , 19 (1965) 303-328.

[21] Knaupp M., Schnering H.G., Inorg. Chem. 33 (1994) 2555-2564.

[22] Vreshch V., Shen W., Nohra B., Yip S.K., Yam V.W.W., Lescop C., Réau R., Chem. Eur. J., 18 (2012) 466-477.

[23] (a) Herrera J.M., Pope S.J.A., Adams H., Faulkner S., Ward M.D., Inorg. Chem., 45 (2006) 3895-3904; (b) Kawakami D., Yamashita M., Matsunaga S., Takaishi S ., Kajiwara T., Miyasaka H., Sugiura K., Matsusaki K., Okamoto H., Wakabajashi Y., Sawa H., Angew. Chem. Int. Ed, 45 (2006) 7214-7217(c) Yuchesan G., Valeich J.E., Liu H., Ouellette W.,. O’Connor C.J, Zubieta J., Inorg. Chim. Acta, 362 (2009) 1831-1839.

[24] (a) Wu J.Y., Hsu H.Y., Chan C.C., Wen Y.S., Tsai C., Lu K.L., Cryst. Growth Des, 19 (2009) 258-262; (b) Nockermann P., Mayer G., Acta Crys., E60 (2004) 744-746; (d) Mahmoudi G., Morsali A., Cryst. Eng. Comm., 11 (2009) 1868-1879.

[25] Addison A.W., Rao T.N., Reedijk J., Van Rijn J., Verschoor J., Dalton Trans., (1984) 1349-1356.

[26] Mahmoudi G., Morsali A., Polyedron, 27 (2008) 1070-1078.

[27] (a) Julve, M., De Munno, G., Bruno, G., Verdaguer, M., Inorg. Chem., 27 (1988) 3160-3165; (b) Alborés P., Rentschler E., Dalton.Trans., (2009) 2609-2615; (c) Dominiquez-Vera J.M., Moreno J.M., Galvez N. , Suarez-Varela J., Colacio E., Kivekas R., Klinga M., Inorg. Chim. Acta, 281 (1998) 95-100; (d) Baca S. G., Pope S.J.A., Adams H., Ward M.D., Inorg. Chem., 47 (2008) 3736-3747; (e) Baca S.G., Malaestean I.L., Keene T.D., Adams H., Ward M.D., Hauser J., Neels A., Decurtis S., Inorg Chem., 47 (2008) 11108-11119.

[28] Draper N.D., Batchelor R.J., Aguiar P.M., Kroeker S., Leznoff D.B., Inorg. Chem., 43 (2004) 6557-6567.

[29] (a) Grdenić D., Sikirica M., Korpar-ćolig B., J. Organometallic Chem., 153 (1978) 1-7; (b) Jòszai R., Beszeda I., Bényei A.C., Fischer A., Kovàcs M., Maliarik M., Nagy P., Shchukarev A., Tòth I., Inorg. Chem. , 44 (2005) 9643-9651;(c) Draper N.D., Katz J.M., Batchelor R.J., Leznoff D.B. P., J. Inorg. Organom., 15 (2005) 47-458; (d) Draper N.D., Batchelor R.J., Leznoff B.D., Cryst. Growth Des., 4 (2004) 621-632; (e) Korćok J.L., Leznoff D.B., Polyedron, 52 (2013) 72-73; (e) Costero M.A., Monrabal E. , Andreu C., Martinez-Mànez R., Soto J., Padilla-Tosta M. , Pardo T., Ochando L.E., Amigò J.M., J. Chem. Soc., Dalton Trans., (2000) 361- 
367; (f) Masciocchi N., Albisetti A.F., Sironi A., Pettinari C., Di Nicola C., Pettinari R., Inorg. Chem., 48 (2009) 5328-5337; (g)

Frey M., Ledésert M., ActaCryst. B27, (1971) 2119-2123;(h) Šćavničar S., Z. Kristallogr., 118 (1963) 248-256.

[30] Neto N., Sbrana G., Muniz-Miranda M., Spectrochim. Acta, 46 (1990) 705- 715.

[31] Ould-Moussa L., Castellà-Ventura M., Kassab E., Poizat O.D.P., Strommen D. P. , Kincaid J. R., J. Raman Spectrosc., 31 (2000) 377-390.

[32] Alexander B.D., Dines T.J., Inorg. Chem., 43 (2004) 342-350.

[33] Julve M., Verdaguer M., De Munno G., Real J. A., Bruno G., Inorg. Chem., 32 (1993) 795-802.

[34] Jonas V., Thiel W., J. Chem. Soc., Dalton Trans., (1999) 3783-3790.

[35] Topaçli A., Akyüz S., Spectrochim. Acta 51 A, (1995) 633-641.

[36] (a) Castro I., Julve M., De Munno G., Bruno G., Real J.A., Lloret F.J. , J. Chem. Soc. Dalton Trans., (1992) 1739-1744; (b) De Munno G., Julve M., Lloret F., Derory A., J. Chem. Soc. Dalton Trans., (1993) 1179-1184; (c) Andrés E. , De Munno G., Julve M., Real J.A., Lloret F., J. Chem. Soc. Dalton Trans., (1993) 2169-2174.

[37] De-Yin W., Ren B., Yu-Xiong J., Xu X., Tian Z., J. Phys. Chem. A, 106 (2002) 9042-9052.

[38] Kashiwabara K., Konaka S., Kimura M., Bull. Chem. Soc. Jpn., 46 (1973) 410-413.

[39] Mayer I., J. Comput. Chem., 28(1) (2007) 204-221.

[40] Spiridonov V. P., Gershikov A. G., Butayev B. S., J. Molec. Struct. , 52 (1979) 53-64.

[41] (a) Barone V., Cauletti C., Lelj F., Piancastelli M.N., Russo N., J. Am. Chem. Soc., 104 (1982) 4571-4578; (b) Krejčik M., Záliš S., Ludwig M. , Matheis W., Kaim W., J. Chem. Soc. Perkin Trans., 2 (1992) 2007-2010.

[42] Chen, W.T., Wang, M.S., Liu, X., Guo, G.C., Huanh, J.S., Crystal Growth Des., 6 (2006) 2289-2300.

[43] Bekiari V., Thiakou K.A., Raptopolou C.R., Perlepes S.P., Lianos P., Journal of Luminescence, 21 (2008) 481-488.

[44] Barbieri A., Accorsi G., Armaroli N., Chem. Commun., (2008) 2185-2193.

[45] Qin-De Liu, Ruiyao Wang, Suning Wang, Dalton Trans., (2004) 2073-2079.

[46]Meng-Sheng Liao, Qian-Er Zhang, Bull. Chem. Soc. Jpn., 72 (1999) 1459-1463.

[48] Sandström M., Persson I., Persson P., Acta Chem. Scand., 44 (1990) 653-675.

[49] (a) Khavasi H.R., Tehrani A.A, Inorg. Chem., 52(6) (2013) 2891-2905; (b) Mahmoudi G., Morsali A. , Cryst. Eng. Comm., 11 (2009) 1868-1879

[50] (a) Cingolani A., Lorenzotti A., Lobbia G.G., Leonesi D., Bonati F., Bovio B., Inorg. Chim.Acta, 132 (1987) 167-176; (b) WenTong Chen, Ming-Sheng Wang, Xi Liu, Guo-Cong Guo, Jin-Shun Huang, Cryst.Growth Des., 6 (2006) 2289-2300; (c) Bing Liu, Guo-Cong Guo, Jin-Shun Huang, J. Solid State Chem., 179 (2006) 3136-3144; (d) Masciocchi N., Albisetti A.F., Sironi A., Pettinari C. , Di Nicola C. , Pettinari R., Inorg.Chem., 48 (2009) 5328-5337.

[51] Mahmoudi G., Morsali A., Ahu L. G., Polyhedron, 26 (2007) 2885-2893. 
